\title{
23. QUATERNARY CARBON ISOTOPE RECORD OF PELAGIC FORAMINIFERS: SITE 806, ONTONG JAVA PLATEAU ${ }^{1}$
}

\author{
H. Schmidt, ${ }^{2}$ W.H. Berger, ${ }^{3}$ T. Bickert, ${ }^{2}$ and G. Wefer ${ }^{2}$
}

\begin{abstract}
We present $\delta^{13} \mathrm{C}$ records spanning the last $2 \mathrm{~m} . y$. of two planktonic foraminiferal taxa (Globigerinoides sacculifer and Pulleniatina) from Ocean Drilling Program Site 806 on the Ontong Java Plateau, western equatorial Pacific. The sampling interval is between 4 and 5 k.y. The two taxa are thought to reflect conditions within the mixed layer and within the bottom of the mixed layer (or in the uppermost thermocline), respectively. The records were analyzed for trends and cycles on time scales greater than $100 \mathrm{k} . \mathrm{y}$. and for periodicity in the orbital portions of the Fourier spectrum. The G. sacculifer record shows a long-term decrease in $\delta^{13} \mathrm{C}$, superimposed on long-period fluctuations. The obliquity-related signal is distinct throughout the Quaternary. The Pulleniatina record shows subdued amplitudes, compared with G. sacculifer.

There is evidence, from comparison of the differences in $\delta^{13} \mathrm{C}$ with those of $\delta^{18} \mathrm{O}$, that a shallowing of the thermocline in the late Quaternary (increase in delta $\delta^{18} \mathrm{O}$ ) was not accompanied by increased contrast in $\delta^{13} \mathrm{C}$ between the two species. One possible explanation is that the oxygen minimum was weakened at the same time as the thermocline shallowed and the mixed layer thickness decreased. In addition, changes in symbiont activity in $G$. sacculifer may be involved.
\end{abstract}

\section{INTRODUCTION}

In the attempt to understand the mechanisms producing climate oscillations in the Quaternary and the role of the ocean with regard to variations in atmospheric $\mathrm{CO}_{2}$, increasing attention has been given to changes in the ocean's carbon cycle, especially its productivity (Sundquist and Broecker, 1985; Berger et al., 1989). The carbon isotope record of foraminifers has become central to this type of paleoceanographic research within the last decade (Broecker, 1982; Shackleton et al., 1983a; Vincent et al., 1985; Boyle and Keigwin, 1986; Curry and Crowley, 1987; Labeyrie et al., 1987; Curry et al., 1988; Duplessy et al., 1988; Sarnthein et al., 1988; Raymoet al., 1990; summaries in Berger and Vincent, 1986; Wefer and Berger, 1991).

Commonly, the $\delta^{13} \mathrm{C}$ records of planktonic and benthic species are compared when drawing conclusions about changes in the efficiency of the "biological pump" or the $\mathrm{pCO}_{2}$ of the atmosphere (Broecker, 1982; Shackleton et al., 1983a; Berger and Spitzy, 1988; Keir, 1988), or else benthic records from different depths, or different basins, are contrasted to obtain clues about changes in deep circulation (e.g., Shackleton et al., 1983b; Kallel et al., 1988; Keir, 1988; Raymo et al., 1990). Here we explore what might be learned from the carbon isotope values of two different planktonic taxa, growing at different depths in upper waters (cf. Vincent and Berger, 1985; Vincent et al., 1985; Berger and Wefer, 1991; Whitman and Berger, this volume).

Our focus is on the western equatorial Pacific. We present a record of carbon isotopic composition of the planktonic taxa $G$. sacculifer and Pulleniatina, spanning the last 2 m.y., and we analyze the record for long-term trends and for periodicities in the orbital portions of the Fourier spectrum. The study area is the Ontong Java Plateau. This region has favorable conditions for the sedimentation of carbonate and represents truly oceanic conditions far away from the influences of continental margins. A strong global component is therefore expected to be present in the stable isotope record. The plateau has long been a favorite locality for studies on the Quaternary stable isotope

\footnotetext{
'Berger, W.H., Kroenke, L.W., Mayer, L.A., et al., 1993. Proc. ODP, Sci. Results, 130: College Station, TX (Ocean Drilling Program).

${ }^{2}$ Fachbereich Geowissenschaften, Universităt Bremen, Postfach 330440, 2800 Bremen 33, Federal Republic of Germany.

${ }^{3}$ Geological Research Division, Scripps Institution of Oceanography, University of California, San Diego, La Jolla, CA 92093 , U.S.A.
}

record (Shackleton and Opdyke, 1973, 1976; Berger and Killingley, 1977; Schiffelbein, 1984; Wu and Berger, 1991; Whitman and Berger, 1992), and for carbonate sedimentation in general (Johnson et al., 1977; Hebbeln et al., 1990; Wu et al., 1990; Grötsch et al., 1991).

\section{MATERIALS, METHODS, AND CONCEPTS}

Hole $806 \mathrm{~B}$ was drilled on the northeastern slope of Ontong Java Plateau $\left(0^{\circ} 19.11^{\prime} \mathrm{N}, 159^{\circ} 21.69^{\prime} \mathrm{E}\right.$; Fig. 1$)$, about $74 \mathrm{nmi}$ northeast of Deep Sea Drilling Project (DSDP) Sites 289 and 586, at a water depth of $2534 \mathrm{~m}$ (Fig. 1). The site is well above the present lysocline (3300-3400 m; Wu and Berger, 1989) and therefore may be expected to yield a continuous record of undisturbed Pliocene and Pleistocene sedimentation. Shipboard biostratigraphic studies suggested sedimentation rates near $20 \mathrm{~m} / \mathrm{m}$.y. for the Quaternary (see Shipboard Scientific Party, 1991). A detailed age model based on counting obliquity cycles in the $\delta^{18} \mathrm{O}$ record of $G$. sacculifer (Berger et al., this volume) confirmed this estimate, yielding an average sedimentation rate only slightly higher.

The samples for this study were obtained from Cores $130-806 \mathrm{~B}-$ $1 \mathrm{H}$ through $-5 \mathrm{H}(0-44.5 \mathrm{~m}$ below seafloor [mbsf]). The cores contain gradationally interbedded layers of white foraminifer nannofossil ooze and nannofossil ooze with foraminifers. The sediment is moderately bioturbated; minor drilling disturbances are restricted to the uppermost $50 \mathrm{~cm}$ of Cores $130-806 \mathrm{~B}-2 \mathrm{H}$ to $-5 \mathrm{H}$. Standard $10-\mathrm{cm}^{3}$ samples were taken at 10 -cm intervals. Approximately $5 \mathrm{~g}$ of wet bulk sediment were freeze-dried, weighed, and wet sieved at $63 \mu \mathrm{m}$. Each sample was ultrasonified twice for about $10 \mathrm{~s}$ during this process.

For each sample, 25 tests, if available, of the two planktonic taxa G. sacculifer and Pulleniatina were picked from the $355-425 \mu \mathrm{m}$ fraction and crushed with a glass pestle. The sample size and narrow size fraction were chosen to minimize the sampling error from intraspecific scatter in isotope values (Berger et al., 1978). For G. sacculifer, only tests that were intact were selected (also, a special effort was made to avoid G. fistulosus). The sample size for isotopic measurement was $60-80 \mu \mathrm{g}$. The carbonate was reacted with orthophosphoric acid at $75^{\circ} \mathrm{C}$. All samples were measured using a Finnigan MAT 251 micromass spectrometer with a Finnigan Automated Carbonate Device at the Geoscience Department of the University of Bremen. Precision was regularly checked with an internal carbonate standard (Solnhofen Limestone); over a 1-yr period (1990) it was $<0.07 \%$ for $\delta^{18} \mathrm{O}$ and $<0.05 \%$ for $\delta^{13} \mathrm{C}(1 \sigma)$. Conversion to the inter- 


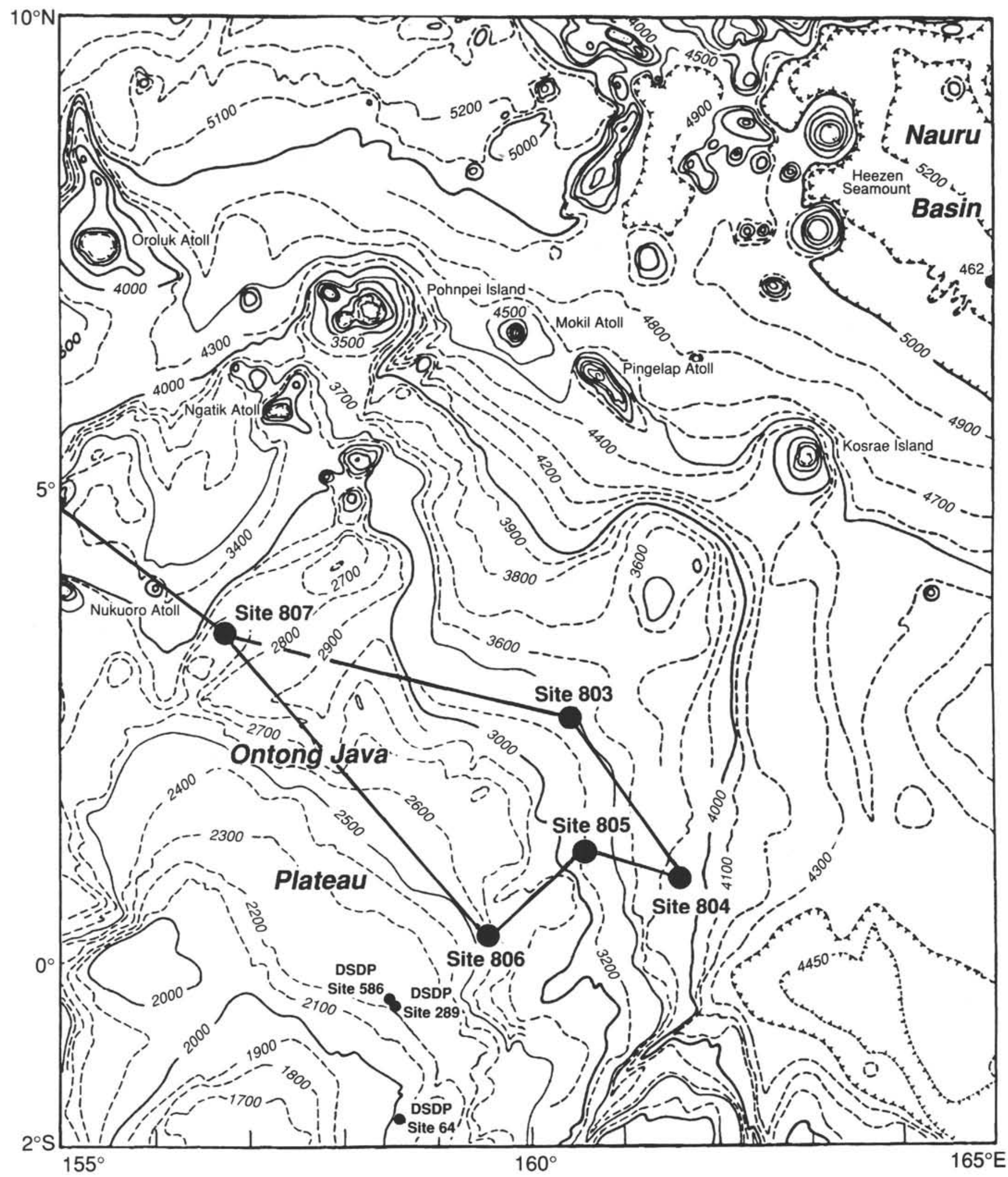

Figure 1. Study area and site locations of Leg 130 (Sites 803-807). Also shown are the positions of DSDP Sites 64, 289, and 586. 
national PeeDee Belemnite (PDB) scale was performed using NBS standards 18,19 , and 20.

The age model adopted here is described in detail in Berger et al. (this volume). It is based on the assumption that the obliquity cycle (4l k.y.) is the driving force for one of the two dominant periods seen in the oxygen isotope record. In this age scale, the Brunhes/Matuyama boundary is dated at 792 k.y., which is virtually identical to the age proposed by Shackleton et al. (1990) for this datum. Sampling intervals, accordingly, are typically between 4 and 5 k.y.

The methodology of interpretation is conventional (see Berger and Vincent, 1986, for summary). Many of these conventions are open to discussion, especially with respect to the "vital effect," including the "vital offset" of stable isotopes as recorded by planktonic foraminifers (see Hemleben et al., 1989, chapter 12; Wefer and Berger, 1991). The $\delta^{13} \mathrm{C}$ value of an individual shell represents a weighted average of $\delta^{13} \mathrm{C}$ in the dissolved inorganic carbon in the water where the shell grew, as well as biological fractionation. The vital effect is especially important in symbiont-bearing species in the stages of rapid growth. Berger et al. (1978) showed that the carbon isotopic composition of planktonic foraminifers in surface sediments on Ontong Java Plateau, including the two taxa selected for this study, are generally lighter than expected for equilibrium with $\Sigma \mathrm{CO}_{2}$ of the ambient seawater. Fairbanks et al. (1982) and Ganssen (1983) reported similar results for these two species from net tows in the Panama Basin and off northwest Africa, respectively. Spero et al. (1991) present a model of vital effects in symbiont-bearing planktonic foraminifers that highlights the various complications involved. They argue that heavier $\delta^{13} \mathrm{C}$ values in the larger shells of $G$. sacculifer are caused by increased symbiont activity rather than precipitation of carbonate closer to equilibrium (as suggested by Berger et al., 1978).

Our data are insufficient for discussion of multivariate causes of $\delta^{13} \mathrm{C}$ fluctuations. We assume that in our data vital effects do not change through time. Long-term trends in background $\delta^{13} \mathrm{C}$ values are therefore ascribed to internal fractionation between different water masses and to global changes caused by the transfer of organic carbon between ocean and biosphere, soil, and marginal sediments (Shackleton, 1977; Vincent and Berger, 1985). It may be safely postulated that terrestrial organic matter is delivered to the ocean during regressions (e.g., Adams et al., 1990), which should lower the oceanic ${ }^{13} \mathrm{C} /{ }^{12} \mathrm{C}$ ratio. Another way to lower this ratio, in the Pacific, is to increase the asymmetry in dissolved $\mathrm{CO}_{2}$ between the Atlantic and the Pacific by an overall increase in North Atlantic Deep Water (NADW) production (Vincent et al., 1980; Shackleton et al., 1983b; Miller and Fairbanks, 1985). The considerably lower $\delta^{13} \mathrm{C}$ values in the Pacific, compared with the Atlantic (Kroopnick, 1985), are a prime marker for the strength of this asymmetry. It would seem reasonable to expect an overall increase in asymmetry from planetary cooling; in fact, there is evidence that this is so (Whitman and Berger, this volume). However, glacial periods within the late Quaternary were characterized by decreased asymmetry (Shackleton et al., 1983b; Raymo et al., 1990).

We take $G$. sacculifer as representing the conditions in the mixed layer, and Pulleniatina as representing conditions near $150 \mathrm{~m}$, that is, at the bottom of the mixed layer or in the uppermost thermocline, depending on the thickness of the mixed layer. Thus, if the mixed layer is very thick, we expect similar records for the two taxa, but if its thickness is reduced, we expect increased contrast in the $\delta^{13} \mathrm{C}$ values and increased independence in the fluctuations. It is possible that the shell output of the two taxa is episodic and therefore reflects different conditions in time rather than in habitat. Seasons, presumably, are weak here in the western equatorial Pacific (Reid, 1969), but interannual variation must be taken into account as well. The difference in stable isotopes between the two taxa reflects, in part, differences in environments at their respective peak seasons, and not only overall changes in the thermocline and the nutricline. In addition, changes in depth habitat of the two taxa studied could influence results.

\section{RESULTS}

The raw data for $\delta^{13} \mathrm{C}$ (both taxa) and $\delta^{18} \mathrm{O}(G$. sacculifer) are presented in Figure 2 and listed in the Appendix. The position of each sample is marked; a connecting line is drawn when the distance between samples is $10 \mathrm{~cm}$ or less. The oxygen isotopes of $G$. sacculifer (given in Berger et al., this volume) are shown for stratigraphic reference. Within each core, the $\delta^{13} \mathrm{C}$ records of the two planktonic taxa tend to follow each other quite closely, whereas the relationships between $\delta^{13} \mathrm{C}$ and $\delta^{18} \mathrm{O}$ are rather obscure at first sight, although there is some evidence for covariation (Fig. 2), such that warm periods show greater $\delta^{13} \mathrm{C}$ values.

To obtain a continuous record for further analysis, we filled the gap at Emiliani Stage 19 (at the core break between 130-806B-2H and $-3 \mathrm{H}$ ) by transferring corresponding data from Hole $805 \mathrm{C}$, using the age model of Berger et al. (this volume). Also, we interpolated across the minor gaps, constructing a resampled record for $10-\mathrm{cm}$ steps. Figure 3 illustrates the difference in the relationship between the $\delta^{13} \mathrm{C}$ record of $G$. sacculifer and that of Pulleniatina, when comparing the last million years with the preceding million years. In the last million years, the two records tend to fluctuate together on long wave lengths, whereas in the million years before that, the parallelism appears in the higher frequencies. Also shown in Figure 3 is the record of difference between the carbon records of the two planktonic taxa $\left(\Delta \delta^{13} \mathrm{C}\right)$. The $\delta^{13} \mathrm{C}$ values of $G$. sacculifer are greater than those for Pulleniatina throughout the last $2 \mathrm{~m}$.y. (that is, $G$. sacculifer is en- riched in ${ }^{13} \mathrm{C}$ in comparison to Pulleniatina). The difference is about $0.77 \% \circ \pm 0.20 \%$ ( $1 \sigma)$, on average. This value is almost identical to the one reported for nearby DSDP Site $586(0.75 \%$ $\pm 0.23 \%$; Whitman and Berger, this volume, table 2 ). As mentioned, the isotopic difference between the two taxa can be attributed to their different depth habitats.

The $\delta^{13} \mathrm{C}$ values of $G$. sacculifer vary between $1.1 \%$ and $2.6 \%$, and those of Pulleniatina between $0.5 \%$ and $1.6 \%$, with a range near $1 \%$ for both species, on a time scale of 10 k.y. Superimposed on the high-frequency fluctuations are low-frequency, low-amplitude changes (Fig. 4). Such low-frequency variations are especially pronounced in the $G$. sacculifer record for the whole time interval, whereas in the Pulleniatina record they are quite subdued until after about 1 m.y. ago. The difference between the two curves (DIF13, $\Delta \delta^{13} \mathrm{C}$ ) decreases from the lower to the upper Quaternary.

Although the general patterns of the two records are similar on a scale of a few 10 to 100 k.y., on the long scale of a few 100 k.y. considerable differences are revealed (Fig. 4). Between about 1.5 and $0.8 \mathrm{Ma}$, the $G$. sacculifer record exhibits an overall trend to lower $\delta^{13} \mathrm{C}$ values, a pattern that is not reproduced by Pulleniatina. Therefore, the records tend to merge. After $0.75 \mathrm{Ma}$ they are rather close together and fluctuate in parallel. The difference (DIF13, $\Delta \delta^{13} \mathrm{C}$ ) curve also reflects these trends: the average value is high $(0.93 \%)$ in the early Quaternary and decreases to $0.62 \%$ in the late Quaternary. The middle Quaternary (between about 1.3 and $0.6 \mathrm{Ma}$ ) is characterized by a transition between these two extremes. These long-term trends and patterns are in good agreement with the results of Whitman and Berger (this volume) for Site 586. These authors present 6-m.y. carbon isotope records for the same two planktonic taxa studied here and, in addition, for two benthic foraminiferal species (Cibicidoides wuellerstorfi and Oridorsalis umbonatus). Their results show that before approximately $2 \mathrm{Ma}$ all four records tend to follow the same general trend toward lighter values moving upward in the section; however, after $2 \mathrm{Ma}$ Pulleniatina values abandon this trend and become slightly greater toward the late Quaternary. The implication for the data presented here is that the $\Delta \delta^{13} \mathrm{C}$ decreases because Pulleniatina deviates from the global trend of ocean waters. Pulleniatina becomes progressively more like $G$. sacculifer in its carbon composition, beginning about $2 \mathrm{Ma}$ ago. Because Pulleniatina is deep-living (and has no symbionts), the trend of decreasing $\Delta \delta^{13} \mathrm{C}$ is most likely of physical rather than biological origin. 

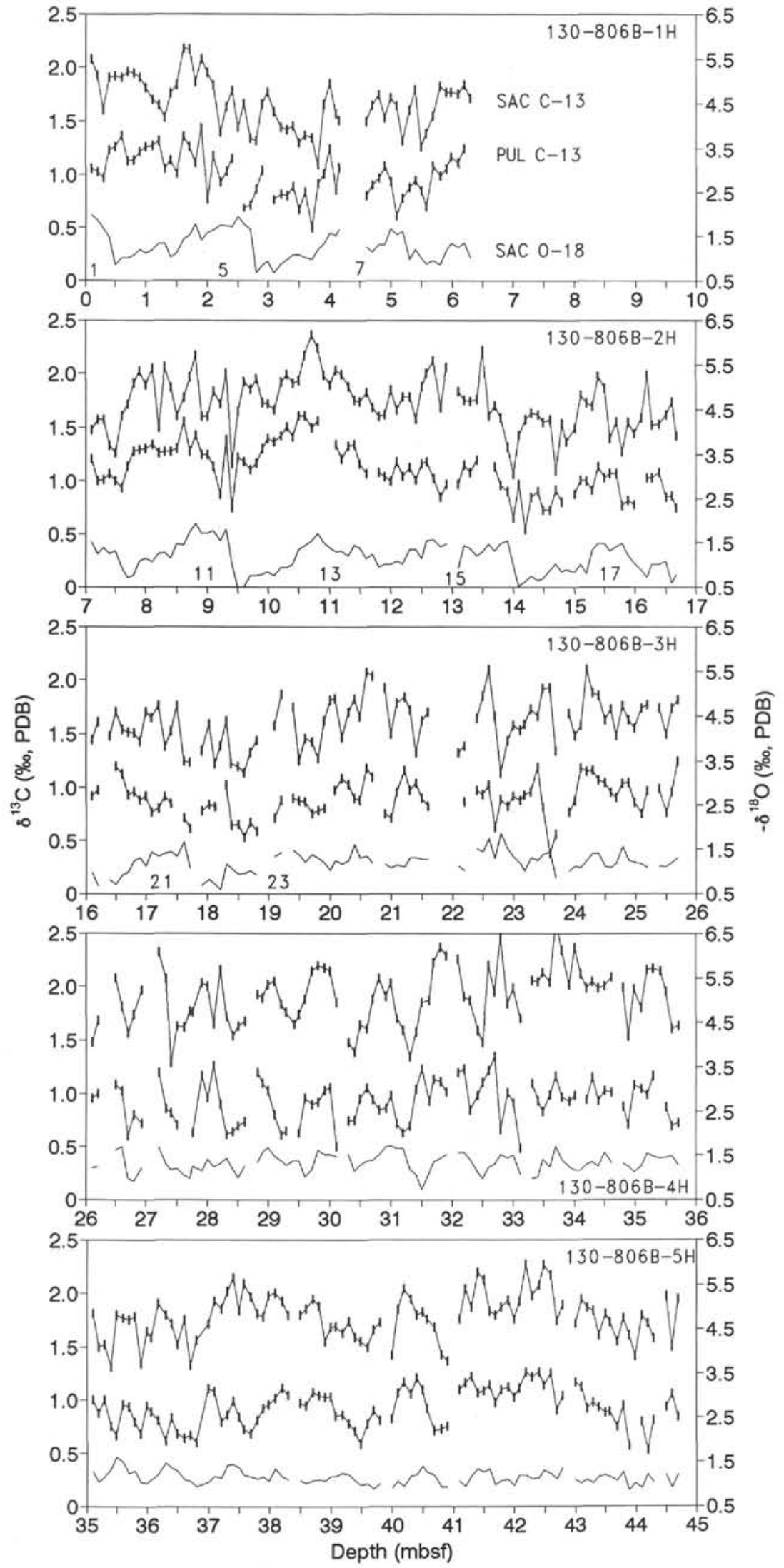

Figure 2. Carbon isotope records of G. sacculifer (SAC C-13) and Pulleniatina (PUL C-13) for the uppermost five cores of Hole 806B. Oxygen isotopes of G. sacculifer (Berger et al., this volume) are shown for stratigraphic reference (SAC O-18; scale on right). Emiliani stage numbers after Shackleton and Opdyke $(1973,1976)$. 


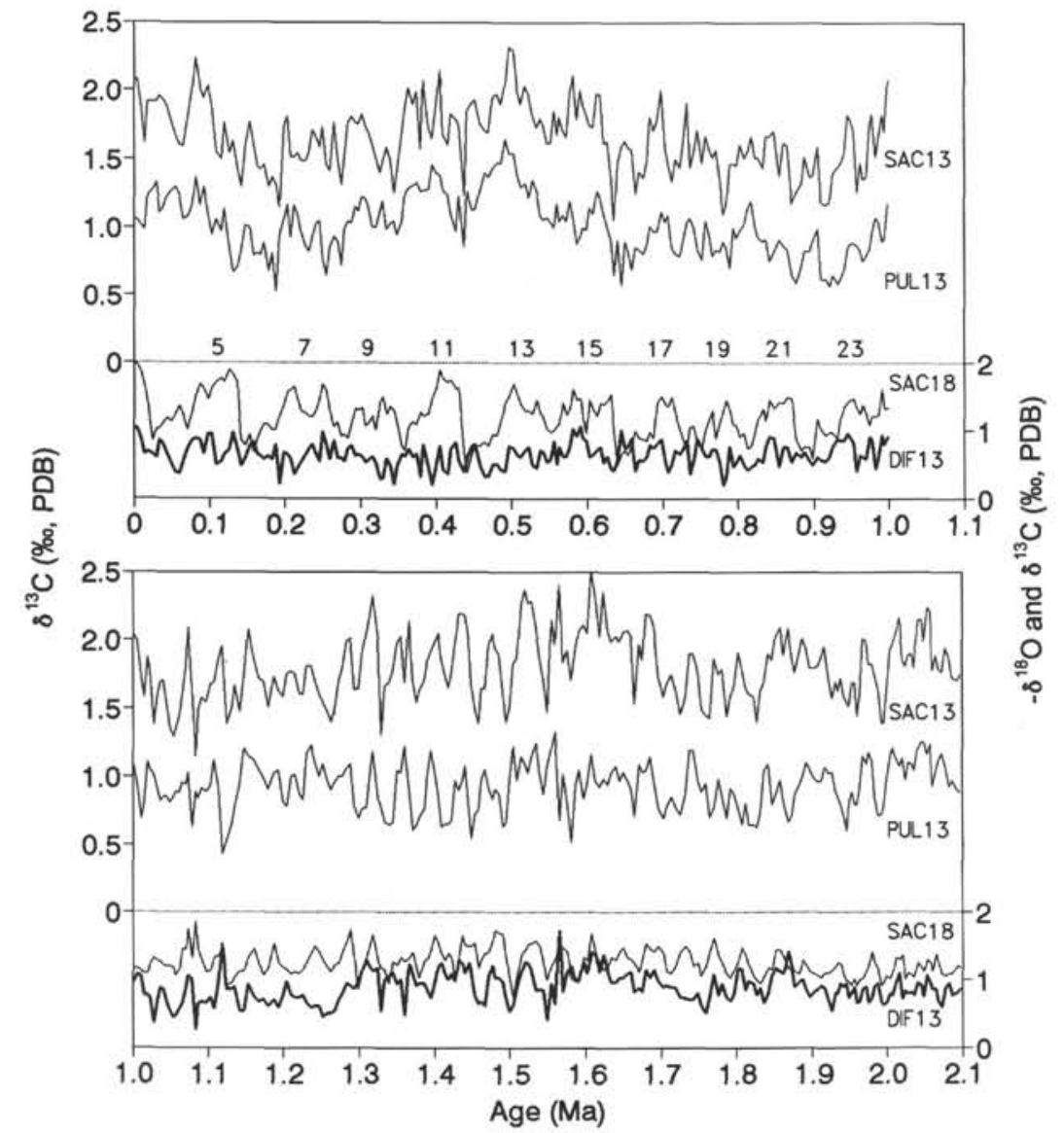

Figure 3. Overview of $\delta^{13} \mathrm{C}$ records of $G$. sacculifer (SAC13) and Pulleniatina (PUL13). Bottom, $\delta^{18} \mathrm{O}$ record of $G$. sacculifer (SAC18, from Berger et al., this volume) and $\Delta \delta^{13} \mathrm{C}$ (G. sacculiferPulleniatina; DIF13, scale on right). Data interpolated (see text) and plotted using the age model of Berger et al. (this volume). Isotope stage numbers as in Figure 2.

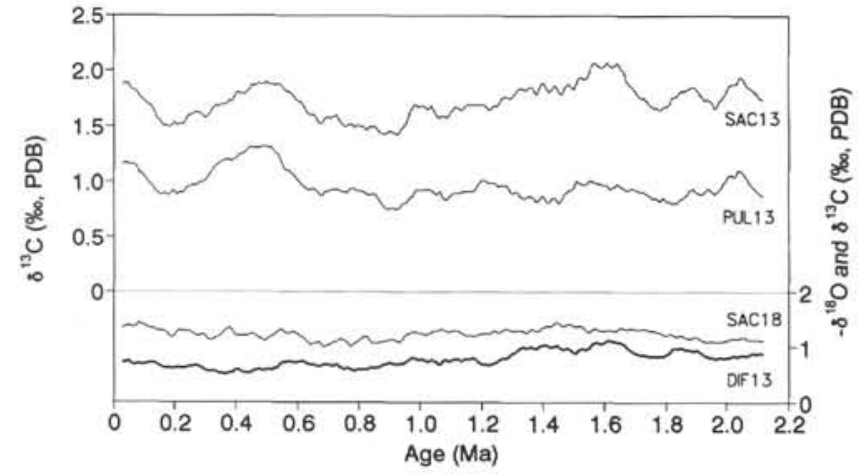

Figure 4. Long-term trends in the $\delta^{13} \mathrm{C}$ records of $\mathrm{G}$. sacculifer and Pulleniatina. Bottom, $\delta^{18} \mathrm{O}$ record of $G$. sacculifer $(\mathrm{SACl} 18)$ and difference record (DIF13 $=\Delta \delta^{13} \mathrm{C}$ of $G$. sacculifer-Pulleniatina; scale on right). Data were smoothed using a running average ( $2-\mathrm{m}$ window, ca. $100 \mathrm{k.y}$.). Symbols as in Figure 3.

\section{DISCUSSION}

\section{Comparison between $G$. sacculifer and Pulleniatina}

The relationships between the $\delta^{18} \mathrm{O}$ and $\delta^{13} \mathrm{C}$ of $G$. sacculifer are explored in Figure 5, and those between the carbon isotope records of G. sacculifer and Pulleniatina in Figure 6, by plotting the paired variables in $\mathrm{x}-\mathrm{y}$ diagrams, two for each core. One can see a weak correlation between $\delta^{18} \mathrm{O}$ and $\delta^{13} \mathrm{C}$ in $G$. sacculifer such that more negative $\delta^{18} \mathrm{O}$ values tend to be associated with more positive $\delta^{13} \mathrm{C}$ values, especially in Cores $130-806 \mathrm{~B}-4 \mathrm{H}$ and $-5 \mathrm{H}$ (Figs. 5D-5E). It appears, then, that there is a slight tendency for enrichment with ${ }^{13} \mathrm{C}$ during interglacials and depletion during glacials. This is parallel to the changes familiar from benthic foraminifers (e.g., Zahn et al., 1986; Curry et al., 1988).

The correlations between the $\delta^{13} \mathrm{C}$ values of the two taxa are moderately good in Cores $130-806 \mathrm{~B}-1 \mathrm{H},-2 \mathrm{H}$, and $-5 \mathrm{H}$ but less so in Cores $130-806 \mathrm{~B}-3 \mathrm{H}$ and $-4 \mathrm{H}$ (Fig. 6). The results of regression analysis show that differences between the $\delta^{13} \mathrm{C}$ records can be attributed largely to excursions within the $G$. sacculifer record: the slope in the regression equations is always distinctly $<1$. In the early to middle Quaternary (Cores $3 \mathrm{H}$ and $4 \mathrm{H}$ ), low correlation coefficients and small slope coefficients reflect the high-amplitude variations and steady change in $\delta^{13} \mathrm{C}$ of $G$. sacculifer that contrast with the relatively constant values of Pulleniatina. In the upper part of Core 130-806B$3 \mathrm{H}$, the records converge as a result of a steep decrease in $\mathrm{G}$. sacculifer $\delta^{13} \mathrm{C}$ values; at the same time, a stronger coupling is developing between the two $\delta^{13} \mathrm{C}$ records. In Cores $130-806 \mathrm{~B}-2 \mathrm{H}$ and $-1 \mathrm{H}$ (Interval A; $0.75 \mathrm{Ma}$ to present), the two records show more or less parallel fluctuations (slope coefficient $>0.5$ and correlation coefficients $>0.6$ ).

Long-term trends noted in Figures 3 and 4 (with an overall decrease of $\delta^{13} \mathrm{C}$ values of $G$. sacculifer and a convergence with the 

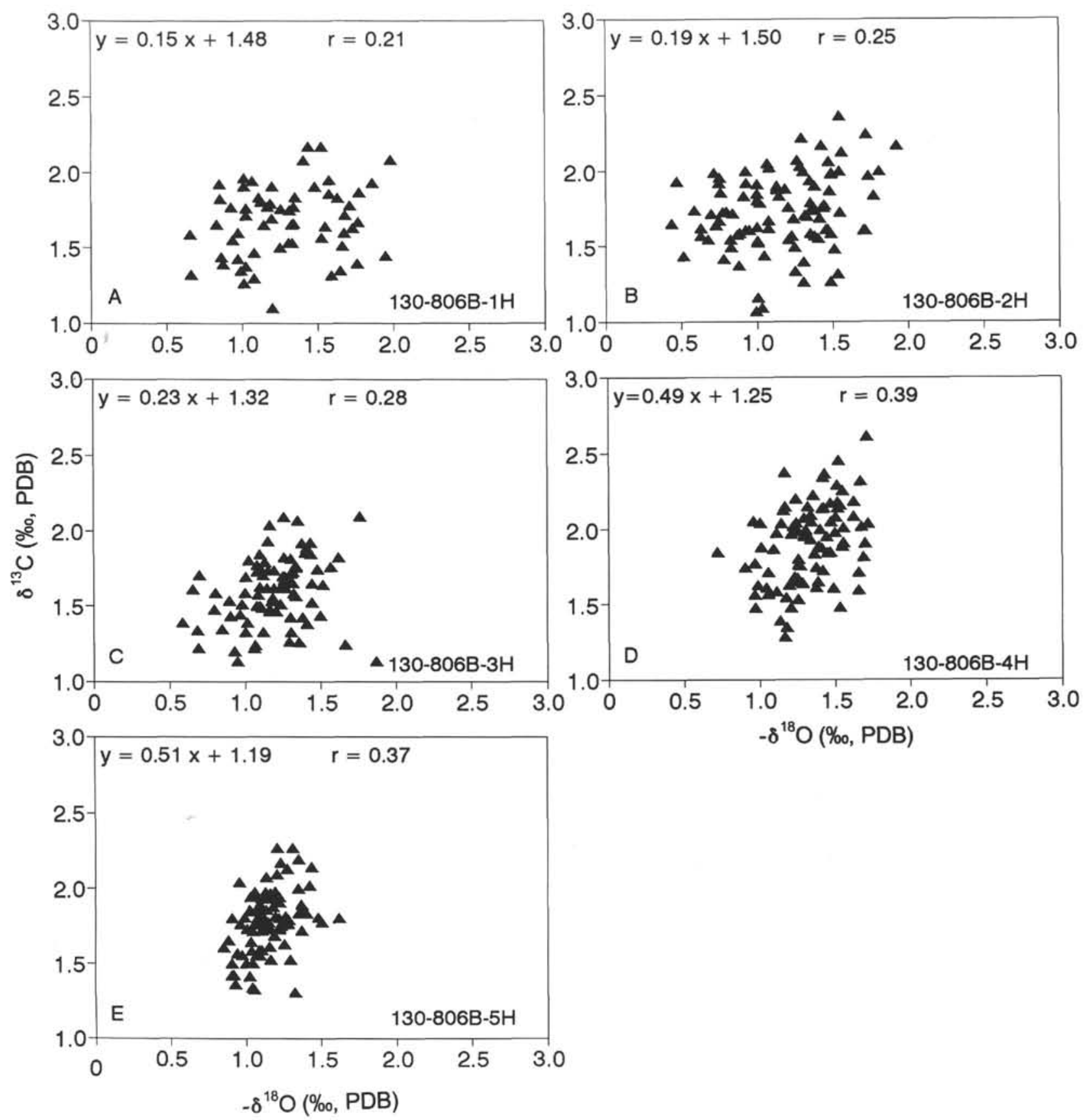

Figure 5. Plot of $\delta^{13} \mathrm{C}$ vs. $\delta^{18} \mathrm{O}$ values for $G$. sacculifer, each core as shown in each panel. Regression equation and correlation coefficient given at top of each panel. Oxygen isotopes from Berger et al. (this volume).

more nearly constant Pulleniatina values) may be further explored by considering the record of differences in $\delta^{18} \mathrm{O}$ and $\delta^{13} \mathrm{C}$ values of the two taxa (Fig. 7). A hint of parallelism between the two difference records on time scales of several 100 k.y. would suggest that when nutrient content is high (large $\Delta \delta^{13} \mathrm{C}$ ) the mixed layer thickness is reduced (large $\Delta \delta^{18} \mathrm{O}$ ). In terms of physical oceanography, this would indicate that an increase in upwelling parallels increased nutrient content in deep waters. One could interpret this to mean, for example, that a general increase in the wind stress parallels increased basin-basin fractionation. This interpretation assumes that Pulleniatina retains its depth habitat through time and that the seasonal relationship in shell production between the two taxa stays more or less constant.
The fact that there is a long-term decrease in $\Delta \delta^{13} \mathrm{C}$ values that is not reflected in a similar decrease in $\Delta \delta^{18} \mathrm{O}$ values (rather, there is an increase in the late Quaternary) indicates that the just-described relationship does not hold on a million-year scale. Instead, as the temperature gradient increased in the latest Quaternary (indicating a shallowing of the thermocline), the contrast in carbon isotope ratios decreased, suggesting a reduced nutrient content of the thermocline. If so, we must assume that basin-basin fractionation was reduced during the late Quaternary (suggesting that there is an optimum for NADW production with respect to planetary cooling; Berger and Wefer, 1991), or that the thermocline was otherwise depleted, for example, by greatly increased sedimentation of organic matter in the ocean margins. 

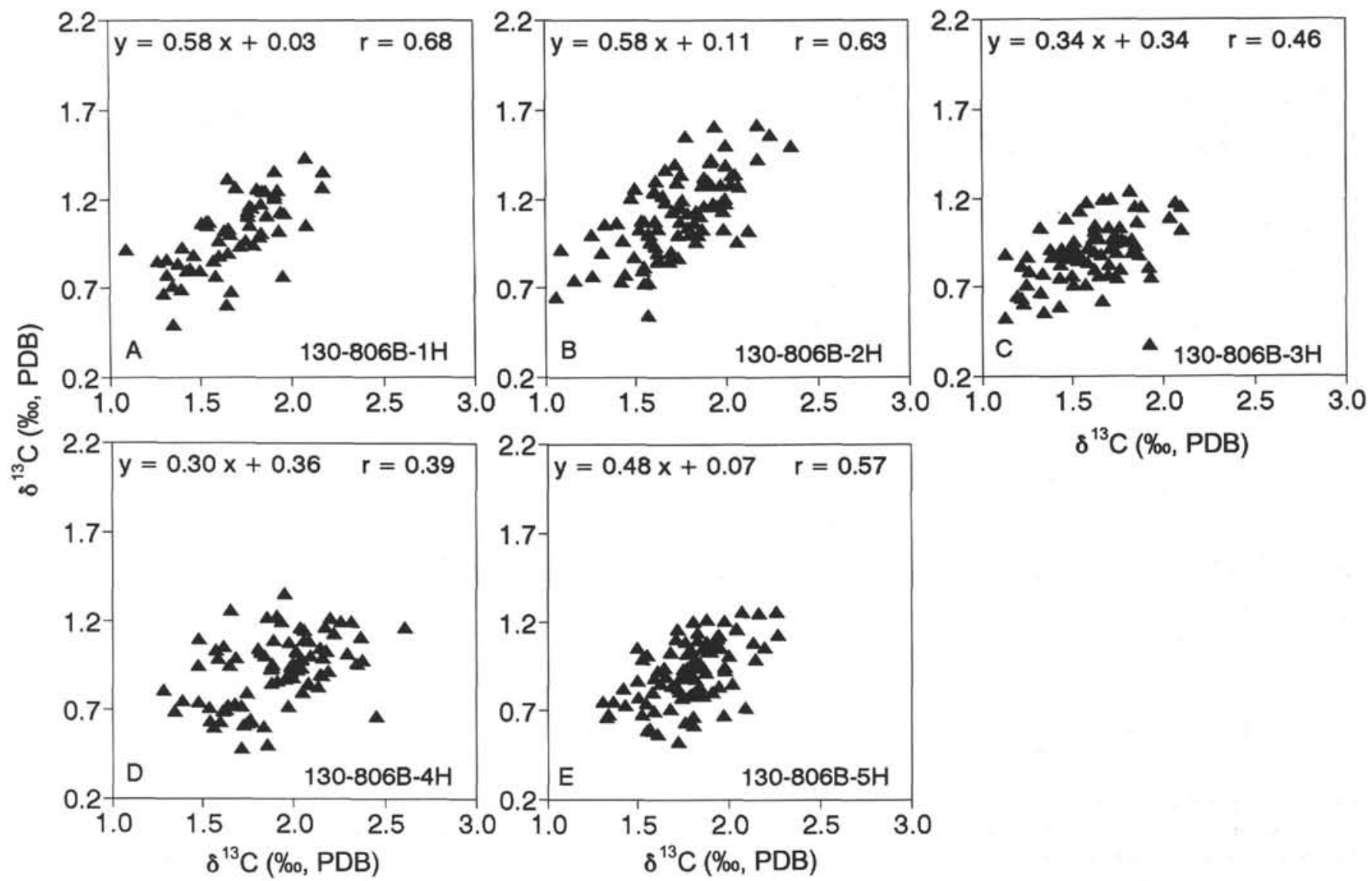

Figure 6. Plot of $\delta^{13} \mathrm{C}$ of Pulleniatina vs. $\delta^{13} \mathrm{C}$ of $G$. sacculifer, each core. Regression equation and correlation coefficient given at top of each panel.

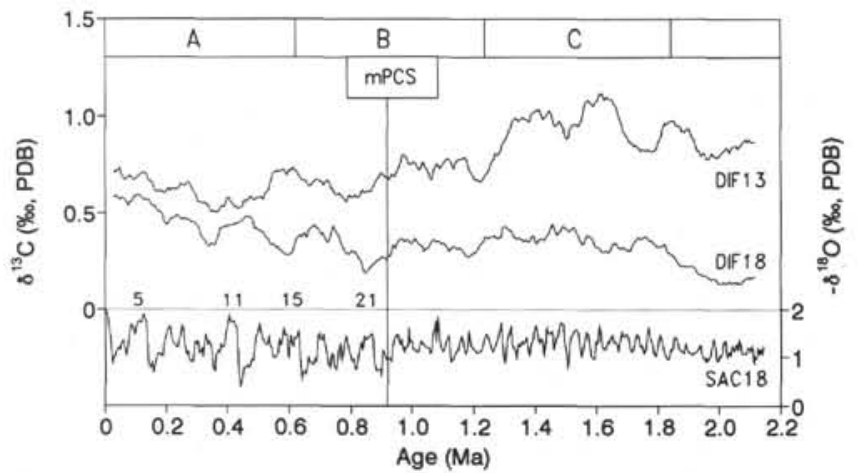

Figure 7. Record of differences in $\delta^{13} \mathrm{C}$ and $\delta^{18} \mathrm{O}$ values, between $G$. sacculifer and Pulleniatina, smoothed as in Figure 4. Oxygen isotopes from Berger et al. (this volume). Divisions A, B, and C (at top of graph) denote the periods labeled "Milankovitch," "Croll," and "Laplace" in Berger and Wefer (in press). Boundaries are crests of 15 th, 30 th, and 45 th obliquity cycles in $\delta^{18} \mathrm{O}$ record, counting backward, and setting $-8 \mathrm{ka}$ to $\mathrm{O}(\mathrm{A} / \mathrm{B}=0.623 \mathrm{Ma} ; \mathrm{B} / \mathrm{C}=1.238 \mathrm{Ma}$; bottom of $\mathrm{C}, 1.845 \mathrm{Ma}$ ). The major mid-Quaternary event is the mid-Pleistocene climate shift at $0.918 \mathrm{Ma}$ (mPCS), when the nature of the $\delta^{18} \mathrm{O}$ record changes drastically (Berger et al., this volume).

The strengthening of the wind system since the latest Pliocene is thought to have induced stronger upwelling worldwide (Arrhenius, 1952; Berger et al., 1989). The overall increase in $\Delta \delta^{18} \mathrm{O}$ values exhibited by the pelagic record from the Ontong Java Plateau is in accord with this hypothesis (Fig. 7). After a minimum shortly before
0.8 m.y., the oxygen isotopic difference between the two taxa continues to increase sharply toward the present. This increase indicates an enhanced temperature difference between the habitats of the two taxa, which we interpret as a shallowing of the thermocline (cf. Whitman and Berger, 1992; Berger et al., this volume). Beginning about 0.35 m.y. ago, the difference in $\delta^{13} \mathrm{C}$ (DIF13) increases together with that in $\delta^{18} \mathrm{O}$ (DIF18), suggesting that a threshold value has been reached where physical coupling of thermocline strength and nutrient gradient outweighs any effects from geochemical nutrient depletion. However, the long-term trend is one of opposition of differences, supporting an hypothesis of late Quaternary thermocline depletion, that is, the concept that some mechanism, as yet unidentified, strips the thermocline of nutrients at the same time when upwelling increases (Berger and Wefer, 1991; Whitman and Berger, this volume). A similar process may be globally active on a glacial-interglacial time scale (cf. Boyle, 1988; Herguera et al., 1991; 1992).

\section{Time Series Analysis}

We investigated the cyclicity of the carbon isotope records for long-term trends and the major orbital cycles (sum of cycles $>90 \mathrm{ka}$, eccentricity, obliquity, and precession), using Fourier analysis. The results are presented in Figures 8 through 11 . The $\delta^{13} \mathrm{C}$ signals are shown as heavy solid lines; $\delta^{18} \mathrm{O}$ signals (from Berger et al., this volume) are also shown for reference and comparison; for major peaks the Emiliani numbers (as given in Shackleton and Opdyke, 1973, 1976) are shown for orientation. The position of these numbers remains the same for Figures 8 through 12 .

Comparison of the long-period fluctuations of $\delta^{18} \mathrm{O}$ and $\delta^{13} \mathrm{C}$ in $G$. sacculifer reveals some interesting similarities and differences in 

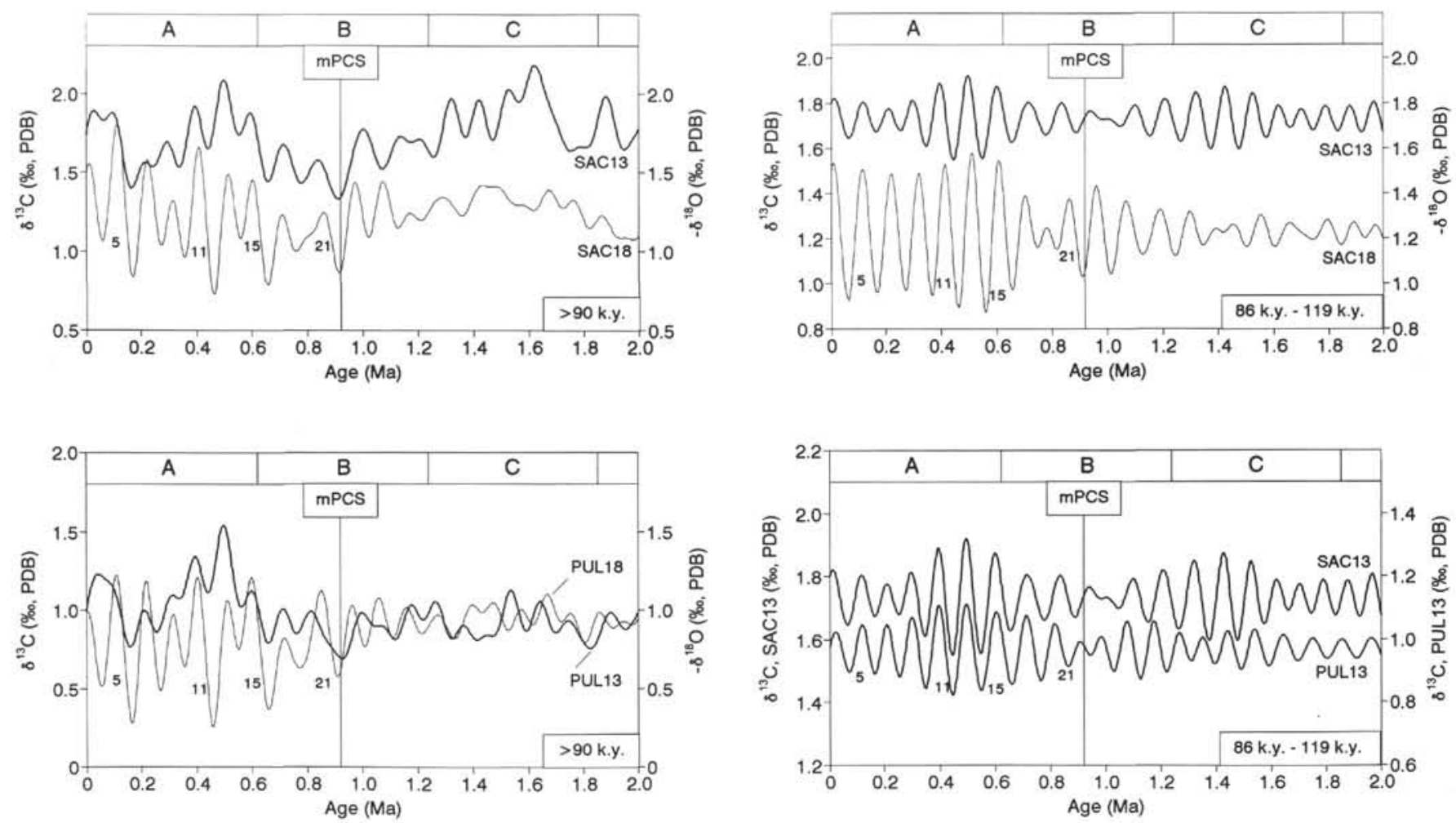

Figure 8. Long-term trends and long-period cycles in the isotope records of G. sacculifer and Pulleniatina, extracted by summing the Fourier terms corresponding to periods greater than 90 k.y. Top, $\delta^{13} \mathrm{C}$ record of $G$. sacculifer, compared with its $\delta^{18} \mathrm{O}$ record. Bottom, $\delta^{13} \mathrm{C}$ record of Pulleniatina, compared with its $\delta^{18} \mathrm{O}$ record. Symbols as in Figure 3 and divisions as in Figure 7.

these two records (Fig. 8A). There is a marked change in the nature of the $\delta^{18} \mathrm{O}$ record near $920 \mathrm{ka}$ (the mid-Pleistocene climate shift [mPCS]; see Berger et al., this volume). In post-shift time, there is a strong dominance of eccentricity-related cycles, whereas before that time no such dominance is in evidence (Fig. $8 \mathrm{~A}$ ). In the $\delta^{13} \mathrm{C}$ record, the mPCS is not strongly expressed, although the position of the boundary marks a prominent $\delta^{13} \mathrm{C}$ minimum. An overall decrease in $\delta^{13} \mathrm{C}$ values, from the early to the late Quaternary also is seen.

A similar comparison of $\delta^{13} \mathrm{C}$ and $\delta^{18} \mathrm{O}$ records of Pulleniatina (Fig. 8B) again shows some indications of parallel fluctuations in the eccentricity-related band (especially in the late Quaternary). Also, the fundamental difference in character of the pre- and post-shift periods is evident for both isotope records. As mentioned previously, in the late Pleistocene the $\delta^{13} \mathrm{C}$ record of Pulleniatina becomes more like that of $G$. sacculifer, presumably reflecting change in surface waters through time. Thus, for Pulleniatina, the reason for the change in character within the Milankovitch period is a stronger coupling to the mechanisms controlling the $G$. sacculifer record.

The relationships between the same isotope records, within the band of eccentricity-related cycles, are illustrated in Figure 9. The eccentricity record of $\delta^{18} \mathrm{O}$ clearly shows a tripartite nature that emerges in the present age model after patching the gap near the Brunhes/Matuyama boundary with data from Hole 805C (Berger and Wefer, in press; Berger et al., this volume). It is characterized by large amplitudes in the time after $700 \mathrm{ka}$, medium amplitudes in the preceding 500 millennia, and low amplitudes before that time. The corresponding intervals are labeled "Milankovitch," "Croll," and "Laplace" in Berger and Wefer (in press) with boundaries at the 15th and 30th crests of $\delta^{18} \mathrm{O}$ obliquity cycles (counting backward and setting crest number zero to $8 \mathrm{ka}$ ). This tripartite structure is not seen in the carbon isotope records. This apparent lack of relevancy of the

Figure 9. Eccentricity-related fluctuations in the stable isotope records of G. sacculifer and Pulleniatina, obtained by summing the Fourier terms corresponding to periods between 86 and $119 \mathrm{ka}$. Top, $\delta^{13} \mathrm{C}$ signal in the $G$. sacculifer record, compared with the corresponding $\delta^{18} \mathrm{O}$ signal. Bottom, comparison of the two $\delta^{13} \mathrm{C}$ signals. Symbols as in Figure 3 and subdivisions as in Figure 7.

carbon records in predicting major features of the $\delta^{18} \mathrm{O}$ record weakens any arguments regarding a strong carbon component in the control of climate within the eccentricity-related time-scale. One notes, in addition, that the $\delta^{18} \mathrm{O}$ cycles tend to "lead" the $\delta^{13} \mathrm{C}$ cycles within the Milankovitch interval (Division A), where both cycles are well expressed. The cycles of the two carbon records tend to be parallel where well expressed (Fig. 9B).

Obliquity-related cycles are well expressed in these records, throughout the 2-m.y. interval studied (Fig. 10). A change in character of the cycles near the mPCS is not evident (instead, the amplitude of the obliquity component in the $\delta^{13} \mathrm{C}$ is at a minimum at shift time). This boundary, then, is a phenomenon largely restricted to eccentricity-related $\delta^{18} \mathrm{O}$ fluctuations. The obliquity-related cycles, on the whole, fluctuate together with almost no shift in the lower half of the record, but with a distinct lead of $\delta^{18} \mathrm{O}$ within the Milankovitch interval. Thus, the poor correlation between $\delta^{18} \mathrm{O}$ and $\delta^{13} \mathrm{C}$ noted earlier is seen to result not from a failure of covariation, but from phase shifts in cycle-dominated records. Changes in phase shift (such as seen in Fig. 10) present an additional complication. Between the carbon records the correspondence is excellent, although the amplitudes are quite small in certain intervals (Fig. 10B). The precessionrelated signals are weak (Fig. 11). They rise but little above the surrounding high-frequency noise. Although the $\delta^{18} \mathrm{O}$ record (SAC18) shows a distinct increase in precession-related amplitude after the mid-Pleistocene climate shift (Fig. 11A), the same is not true for the $\delta^{13} \mathrm{C}$ records (Fig. 11B).

The record of difference in the $\delta^{13} \mathrm{C}$ of the two planktonic taxa was referred to previously. In Figure 12 we show the long-period ( $>90 \mathrm{ka}$ ) component of this record, compared with the corresponding $\delta^{18} \mathrm{O}$ signal from $G$. sacculifer. Three stages are delineated roughly corre- 

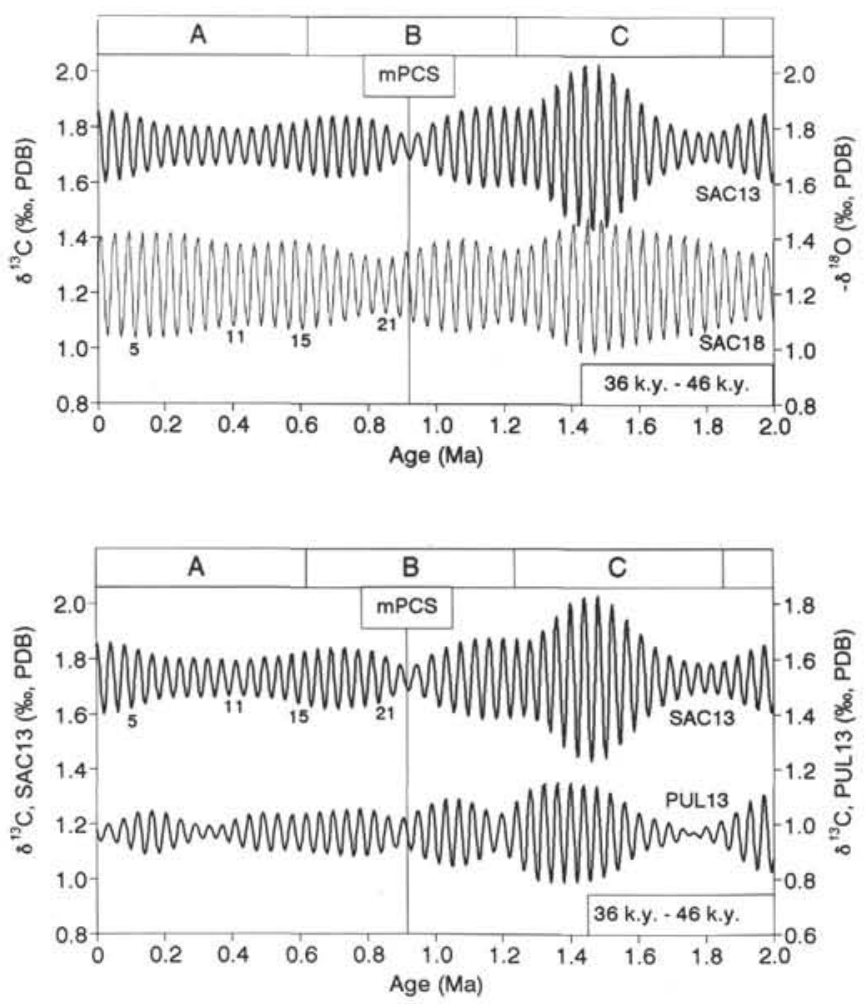

Figure 10. Obliquity-related fluctuations in the stable isotope records of G. sacculifer and Pulleniatina, obtained by summing the Fourier terms corresponding to periods between 36 and $46 \mathrm{ka}$. Top, $\delta^{13} \mathrm{C}$ signal in the $G$. sacculifer record, compared with the corresponding $\delta^{18} \mathrm{O}$ signal. Bottom, comparison of the two $\delta^{13} \mathrm{C}$ signals. Symbols as in Figure 3 and subdivisions as in Figure 7.

sponding to the three Fourier epochs mentioned. The earliest stage (C) shows large differences in $\delta^{13} \mathrm{C}$ values, and the latest (A) shows small ones. The transition zone (B) has intermediate differences. We conclude that the structure of the uppermost water column was fundamentally changed during the last $2 \mathrm{~m} . \mathrm{y}$., simultaneously with the climatic change that increased the importance of eccentricityrelated periodicity in climatic fluctuation.

The distribution of power in the Fourier spectra (Fig. 13) shows that obliquity and long-wave trends are dominant in the $\delta^{13} \mathrm{C}$ records. In contrast, in the $\delta^{18} \mathrm{O}$ records, much of the variance is accounted for in the eccentricity band, especially in the second half of the Quaternary, as mentioned (e.g., Fig. 12). Also, it appears that $\delta^{13} \mathrm{C}$ values of $G$. sacculifer are generally more strongly affected by orbital forcing than are the $\delta^{13} \mathrm{C}$ values of Pulleniatina. Apparently, the oceanic response to orbitally forced climate variations is recorded best in the shallow-water environment of $G$. sacculifer and not in the deeper one of Pulleniatina (a conclusion that is analogous to that reached by Emiliani, 1955).

\section{SUMMARY}

We presented $\delta^{13} \mathrm{C}$ records of $G$. sacculifer and Pulleniatina for the past 2 m.y. and analyzed them for long-term trends and for periodicities corresponding to orbital cycles. The covariance between the two taxa is not very strong $(R=0.66$ and lower). Thus, although similar mechanisms may rule the changes in $\delta^{13} \mathrm{C}$, the mix of these mechanisms is different for the two taxa, presumably because of their different habitats of growth within the water column.

Between about 1.6 and $0.8 \mathrm{~m}$.y. ago, only the G. sacculifer $\delta^{13} \mathrm{C}$ signal describes a general trend toward lower values. The one of
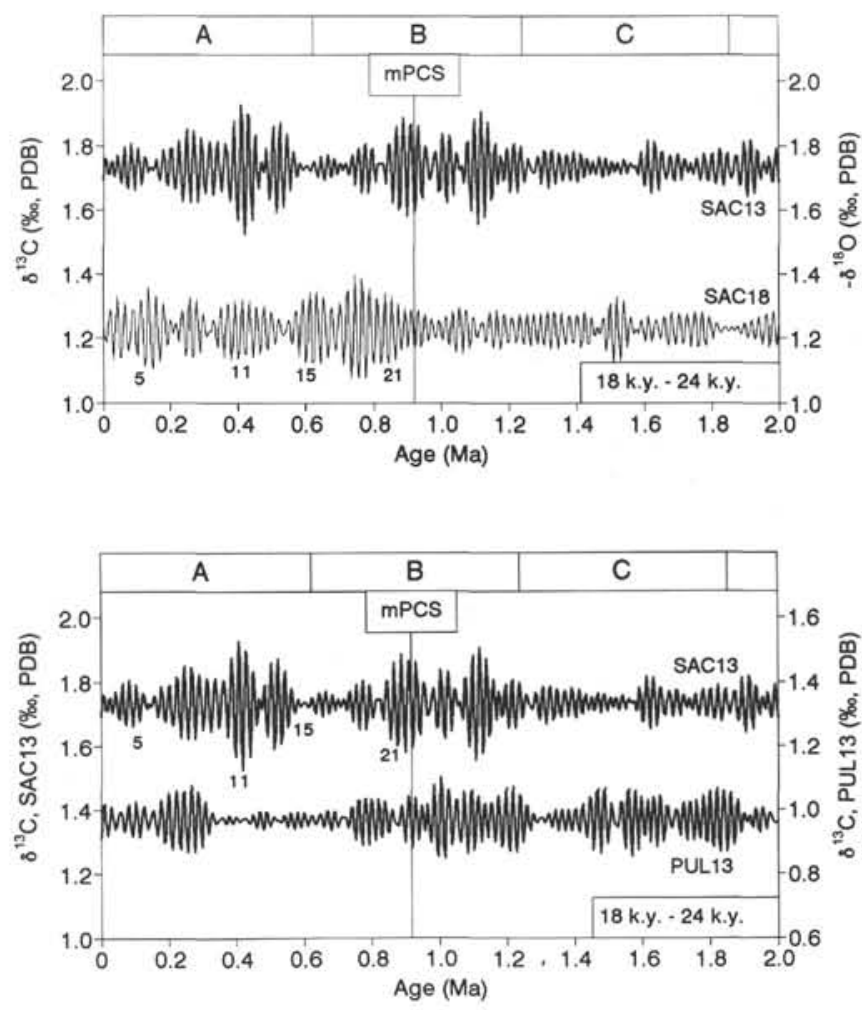

Figure 11. Precession-related fluctuations in the stable isotope records of G. sacculifer and Pulleniatina, obtained by summing the Fourier terms corresponding to periods between 18 and $24 \mathrm{ka}$. Top, $\delta^{13} \mathrm{C}$ signal in the $G$. sacculifer record, compared with the corresponding $\delta^{18} \mathrm{O}$ signal. Bottom, comparison of the two $\delta^{13} \mathrm{C}$ signals. Symbols as in Figure 3 and subdivisions as in Figure 7.

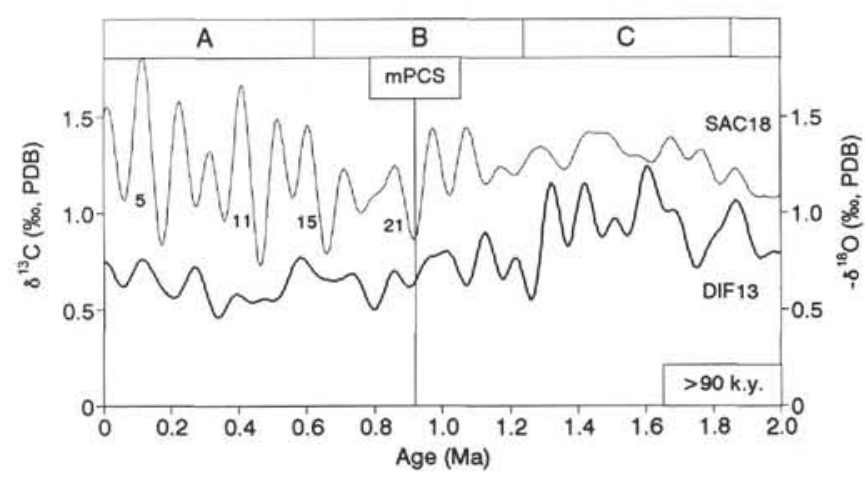

Figure 12. Long-term trends and long-period cycles in the difference in $\delta^{13} \mathrm{C}$ values of $G$. sacculifer and Pulleniatina. Oxygen isotopes of $G$. sacculifer for comparison, filtered in the same fashion (sum of Fourier terms for periods $>90 \mathrm{ka}$ ). Symbols as in Figure 3 and subdivisions as in Figure 7.

Pulleniatina remains at rather constant levels. After about 0.8 m.y. ago, the two records converge and show strong coherency. In this interval, the thermocline shallows (as shown by an increase in $\Delta \delta^{18} \mathrm{O}$ ), but the difference in $\delta^{13} \mathrm{C}$ does not increase likewise, suggesting a decrease of nutrient concentrations in the thermocline (i.e., a weakening of the oxygen minimum below the upwelling zone).

The obliquity-related portion of the Fourier spectrum shows the most power among the various orbital bands for the $\delta^{13} \mathrm{C}$ records of the two pelagic taxa studied. The $G$. sacculifer record generally responds more strongly to orbital forcing than does that of Pulleniatina, 
implying that global climatic variations are best expressed in the shallow-water environment, whereas the habitat near the top of the thermocline is influenced by a more complicated mix of oceanic parameters, whose various effects tend to oppose each other and obscure the underlying regularities.

\section{ACKNOWLEDGMENTS}

We thank our shipmates of Leg 130 for assistance rendered on board the JOIDES Resolution and for helpful discussions. Funding for W.H.B. was provided by the National Science Foundation (OCE 89-00074 and OCE 90-17717), and for T.B., H.S., and G.W. by the Deutsche Forschungsgemeinschaft (DFG Grant No. We 992/12-1). The authors are indebted to Uwe Kuller, Robert Rapp, and Werner Schmidt for assistance in preparing the samples and to Monika Segl, Birgit Meyer, and Istvan Pesza for their scrupulous attention to detail in keeping the mass spectrometer in good working order. N. Shackleton and W. Showers read an earlier version of the manuscript; their frank and helpful criticism is much appreciated.

\section{REFERENCES*}

Adams, J.M., Faure, H., Faure-Denard, L., McGlade, J.M., and Woodward, F.I., 1990. Increases in terrestrial carbon storage from the last glacial maximum to the present. Nature, 348:711-714.

Arrhenius, G., 1952. Sediment cores from the east Pacific. Rep. Swed. DeepSea Exped. 1947-1948, 5:1-227.

Berger, W.H., and Killingley, J.S., 1977. Glacial-Holocene transition in deepsea carbonates: selective dissolution and the stable isotope signal. Science, 197:563-566.

Berger, W.H., Killingley, J.S., and Vincent, E., 1978. Stable isotopes in deep-sea carbonates: box cores ERDC-92, west equatorial Pacific. Oceanol. Acta, 1:203-216.

Berger, W.H., Smetacek, V.S., and Wefer, G. (Eds.), 1989. Productivity of the Ocean: Present and Past: New York (Wiley-Interscience).

Berger, W.H., and Spitzy, A., 1988. History of atmospheric $\mathrm{CO}_{2}$ : constraints from the deep-sea record. Paleoceanography, 3:401-411.

Berger, W.H., and Vincent, E., 1986. Deep-sea carbonates: reading the carbonisotope signal. Geol. Rundsch., 75:249-269.

Berger, W.H., and Wefer, G., 1991. Productivity of the glacial ocean: discussion of the iron hypothesis. Limnol. Oceanogr., 36:1899-1918.

Berger, W.H., and Wefer, G., in press. Klimageschichte aus Tiefseesedimenten-Neues vom Ontong Java Plateau (Westpazifik). Naturwissenschaften, No. 70.

Boyle, E.A., 1988. The role of vertical chemical fractionation in controlling late Quaternary atmospheric carbon dioxide. J. Geophys. Res., 93:15701-15714.

Boyle, E.A., and Keigwin, L.D., 1986. Comparison of Atlantic and Pacific paleochemical records for the last 215,000 years: changes in deep ocean circulation and chemical inventories. Earth Planet. Sci. Lett., 76:135-150.

Broecker, W.S., 1982. Ocean chemistry during glacial time. Geochim. Cosmochim. Acta, 46:1689-1705.

Curry, W.B., and Crowley, T.J., 1987. The $\delta^{13} \mathrm{C}$ of equatorial Atlantic surface waters: implications for ice-age $\mathrm{pCO}_{2}$ levels. Paleoceanography, 2:489-517.

Curry, W.B., Duplessy, J.C., Labeyrie, L.D., and Shackleton, N.J., 1988. Changes in the distribution of $\delta^{13} \mathrm{C}$ of deep water $\mathrm{\Sigma CO}_{2}$ between the last glacial and the Holocene. Paleoceanography, 3:317-341.

Duplessy J.C., Shackleton, N.J., Fairbanks, R.G., Labeyrie, L., Oppo, D., and Kallel, N., 1988. Deep-water source variations during the last climatic cycle and their impact on global deep-water circulation. Paleoceanography, 3:343-360.

Emiliani, C., 1955. Pleistocene temperatures. J. Geol., 63:538-578.

Fairbanks, R.G., Sverdlove, M., Free, R., Wiebe, P.H., and Bé, A.W.H., 1982. Vertical distribution and isotopic fractionation of living planktonic foraminifera from the Panama Basin. Nature, 298:841-844.

* Abbreviations for names of organizations and publication titles in ODP reference lists follow the style given in Chemical Abstracts Service Source Index (published by American Chemical Society).
Ganssen, G., 1983. Dokumentation von küstennahem Auftrieb anhand stabiler Isotope in rezenten Foraminiferen vor Nordwest-Afrika. "Meteor" Forschungsergeb., Reihe C, 37:1-46.

Grötsch, J., Wu, G., and Berger, W.H., 1991. Carbonate cycles in the Pacific: reconstruction of saturation fluctuations. In Einsele, G., Ricken, W., and Seilacher, A. (Eds.), Cycles and Events in Stratigraphy: Heidelberg (Springer-Verlag), $110-125$

Hebbeln, D., Wefer, G., and Berger, W.H., 1990. Pleistocene dissolution fluctuations from apparent depth of deposition in Core ERDC-127P, westequatorial Pacific. Mar. Geol., 92:165-176.

Hemleben, C., Spindler, M., and Anderson, O.R., 1989. Modern Planktonic Foraminifera: Berlin (Springer-Verlag).

Herguera, J.C., Jansen, E., and Berger, W.H., 1992. Evidence for a bathyal front at 2000-m depth in the glacial Pacific, based on a depth transect on Ontong Java Plateau. Paleoceanography, 7:273-288.

Herguera, J.C., Stott, L.D., and Berger, W.H., 1991. Glacial deep-water properties in the west-equatorial Pacific: bathyal thermocline near a depth of 2000 m. Mar. Geol., 100:201-206.

Johnson, T.C., Hamilton, E.L., and Berger, W.H., 1977. Physical properties of calcareous ooze: control by dissolution at depth. Mar. Geol., 24:259-277.

Kallel, N., Labeyrie, L.D., Juillet-Leclerc, A., and Duplessy, J.C., 1988. A deep hydrological front between intermediate and deep-water masses in the glacial Indian Ocean. Nature, 333:651-655.

Keir, R.S., 1988. On the late Pleistocene ocean geochemistry and circulation. Paleoceanography, 3:413-445.

Kroopnick, P., 1985. The distribution of ${ }^{13} \mathrm{C}$ of $\mathrm{\Sigma CO}_{2}$ in the world oceans. Deep-Sea Res., Pt. A, 32:57-84.

Labeyrie, L.D., Duplessy, J.C., and Blanc, P.L., 1987. Variations in mode of formation and temperature of oceanic deep waters over the past 125,000 years. Nature, 327:477-482.

Miller, K.G., and Fairbanks, R.G., 1985. Oligocene to Miocene carbon isotope cycles and abyssal circulation changes. In Sundquist, E.J., and Broecker, W.S. (Eds.), The Carbon Cycle and Atmospheric $\mathrm{CO}_{2}:$ Natural Variations Archean to Present. Am. Geophys. Union, Geophys. Monogr. Ser., 32:469-486.

Raymo, M.E., Ruddiman, W.F., Shackleton, N.J., and Oppo, D.W., 1990. Evolution of global ice volume and Atlantic-Pacific $\delta^{13} \mathrm{C}$ gradients over the last 2.5 m.y. Earth Planet. Sci. Lett., 97:353-368.

Reid, J.L., 1969. Sea-surface temperature, salinity and density of the Pacific Ocean in summer and in winter. Deep-Sea Res., Pt. A, 16 (Suppl.):215-224.

Sarnthein, M., Winn, K., Duplessy, J.-C., and Fontugne, M.R., 1988. Global variations of surface ocean productivity in low and mid latitudes: influence on $\mathrm{CO}_{2}$ reservoirs of the deep ocean and atmosphere during the last 21,000 years. Paleoceanography, 3:361-399.

Schiffelbein, P.A., 1984. Stable isotope systematics in Pleistocene deep-sea sediment records [Ph.D. dissert.]. Univ. of Calif., San Diego.

Shackleton, N.J., 1977. Carbon-13 in Uvigerina: tropical rainforest history and the equatorial Pacific carbonate dissolution cycles. In Andersen, N.R., and Malahoff, A. (Eds.), The Fate of Fossil Fuel $\mathrm{CO}_{2}$ in the Oceans: New York (Plenum), 401-427.

Shackleton, N.J., Berger, A., and Peltier, W.R., 1990. An alternative astronomical calibration of the lower Pleistocene timescale based on ODP Site 677. Trans. R. Soc. Edinburgh, Earth Sci., 81:251-261.

Shackleton, N.J., Hall, M.A., Line, J., and Chuxi, C., 1983a. Carbon isotope data in Core V19-30 confirm reduced carbon dioxide in the ice age atmosphere. Nature, 306:319-322.

Shackleton, N.J., Imbrie, J., and Hall, M., 1983b. Oxygen and carbon isotope record of east Pacific Core V19-30: implications for the formation of deep water in the Late Pleistocene North Atlantic. Earth Planet. Sci. Lett., 65:233-266.

Shackleton, N.J., and Opdyke, N.D., 1973. Oxygen isotope and paleomagnetic stratigraphy of equatorial Pacific core V28-238: oxygen isotope temperatures and ice volumes on a $10^{5}$ year and $10^{6}$ year scale. Quat. Res., 3:39-55.

, 1976. Oxygen-isotope and paleomagnetic stratigraphy of Pacific Core V28-239: late Pliocene to latest Pleistocene. In Cline, R.M., and Hays, J.D. (Eds.), Investigations of Late Quaternary Paleoceanography and Paleoclimatology. Mem.-Geol. Soc. Am., 145:449-464.

Shipboard Scientific Party, 1991. Site 806. In Kroenke, L.W., Berger, W.H., Janecek, T.R., et al., 1991. Proc. ODP, Init. Repts., 130: College Station, TX (Ocean Drilling Program), 291-368.

Spero, H.J., Lerche, I., and Williams, D.F., 1991. Opening the carbon isotope "vital effect" black box; 2:quantitative model for interpreting foraminiferal carbon isotope data. Paleoceanography, 6:639-655. 
Sundquist, E.T., and Broecker, W.S. (Eds.), 1985. The Carbon Cycle and Atmospheric $\mathrm{CO}_{2}$ : Natural Variations Archean to Present. Am. Geophys. Union, Geophys. Monogr. Ser., 32.

Vincent, E., and Berger, W.H., 1985. Carbon dioxide and polar cooling in the Miocene: the Monterey Hypothesis. In Sundquist, E., and Broecker, W.S. (Eds.), The Carbon Cycle and Atmospheric $\mathrm{CO}_{2}$ : Natural Variations Archean to Present. Am. Geophys. Union, Geophys. Monogr. Ser., 32:455-468.

Vincent, E., Killingley, J.S., and Berger, W.H., 1980. The Magnetic Epoch-6 carbon shift: a change in the ocean's ${ }^{13} \mathrm{C} /{ }^{12} \mathrm{C}$ ratio 6.2 million years ago. Mar. Micropaleontol., 5:185-203.

, 1985. Miocene oxygen and carbon isotope stratigraphy of the tropical Indian Ocean. In Kennett, J.P. (Ed.), The Miocene Ocean: Paleoceanography and Biogeography. Mem.-Geol. Soc. Am., 163:103-130.

Wefer, G., and Berger, W.H., 1991. Isotope paleontology: growth and composition of extant calcareous species. Mar. Geol., 100:207-248.

Whitman, J.M., and Berger, W.H., 1992. Pliocene-Pleistocene oxygen isotope record of Site 586, Ontong Java Plateau. Mar. Micropaleontol., 18:171-198.

\section{A}
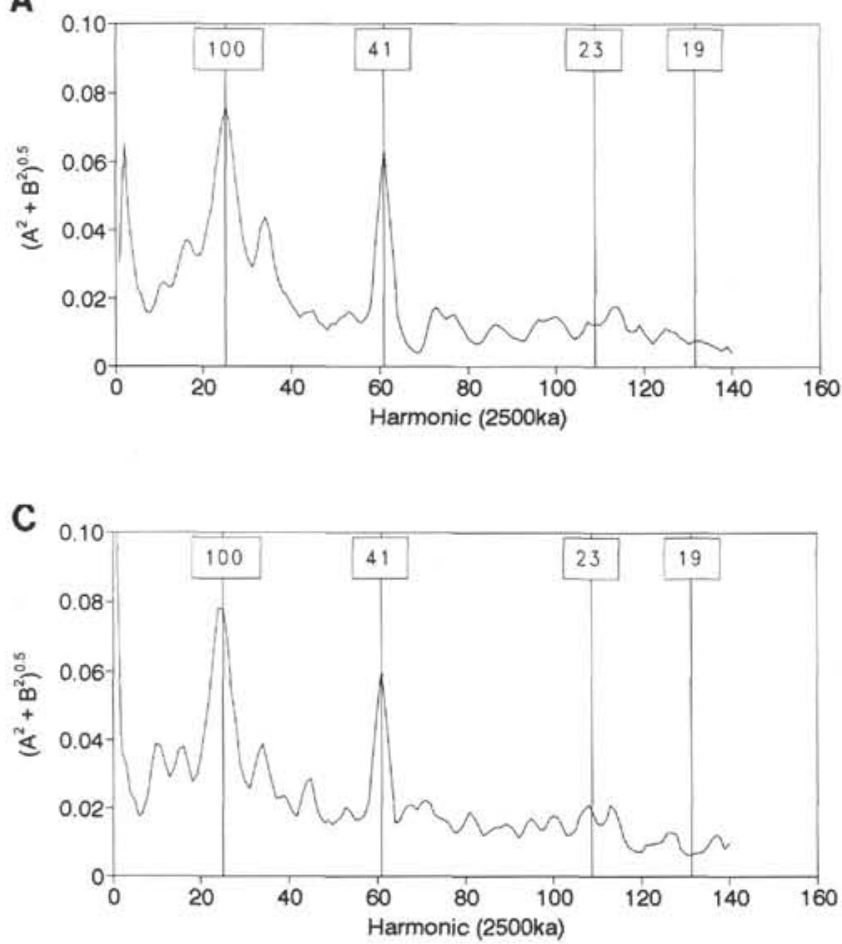

Wu, G., and Berger, W.H., 1989. Planktonic foraminifera: differential dissolution and the Quaternary stable isotope record in the west-equatorial Pacific. Paleoceanography, 4:181-198.

1991. Pleistocene $\delta^{18} \mathrm{O}$ records from Ontong-Java Plateau: effects of winnowing and dissolution. Mar. Geol., 96:193-209.

Wu, G., Herguera, J.C., and Berger, W.H., 1990. Differential dissolution: modification of late Pleistocene oxygen isotope records in the western equatorial Pacific. Paleoceanography, 5:581-594.

Zahn, R., Winn, K., and Sarnthein, M., 1986. Benthic foraminiferal $\delta^{13} \mathrm{C}$ and accumulation rates of organic carbon: Uvigerina peregrina group and Cibicidoides wuellerstorfi. Paleoceanography, 1:27-42.

Date of initial receipt: 5 November 1991

Date of acceptance: 18 October 1992

Ms 130B-024

\section{B}
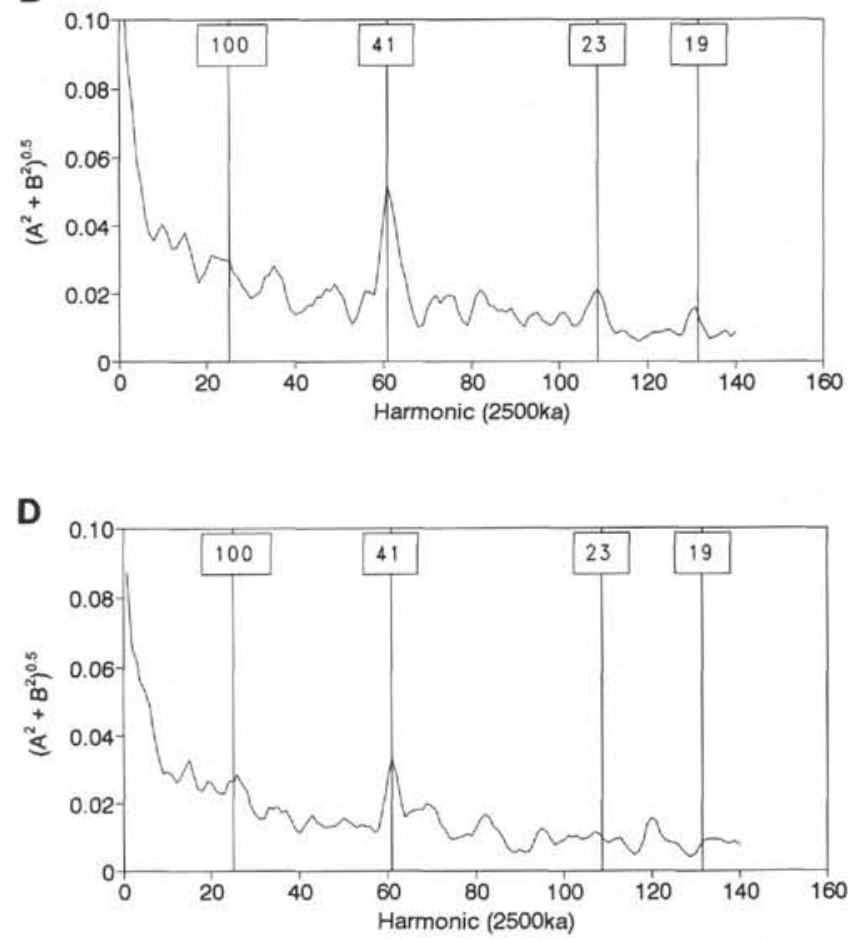

Figure 13. Fourier spectrum of stable isotope records of $G$. sacculifer and Pulleniatina, given as geometric mean of sine and cosine coefficients, as a function of the harmonic to the base of $2500 \mathrm{k}$.y. (The base of 2500 was constructed by extending ends of actual record, using tapered repetition of data between 0 and 204 $\mathrm{ka}$ for the front end, and between 2020 and $2144 \mathrm{ka}$ for the back end, the taper converging to the overall mean of sequence). A. $\delta^{18} \mathrm{O}$ of $G$. sacculifer (data from Berger et al., this volume). B. $\delta^{13} \mathrm{C}$ of $G$. sacculifer. C. $\delta^{18} \mathrm{O}$ of Pulleniatina (data from Berger et al., this volume). D. $\delta^{13} \mathrm{C}$ of Pulleniatina. 


\section{APPENDIX}

Raw isotope data, $\delta^{18} \mathrm{O}$ and $\delta^{13} \mathrm{C}$ of $\mathrm{G}$. sacculifer and $\delta^{13} \mathrm{C}$ of Pulleniatina

\begin{tabular}{|c|c|c|c|c|c|c|c|c|c|c|c|}
\hline \multirow{2}{*}{$\begin{array}{l}\text { Depth } \\
\text { (mbsf) }\end{array}$} & \multicolumn{2}{|c|}{ G. sacculifer } & \multirow{2}{*}{$\begin{array}{l}\text { Pulleniatina } \\
\qquad \delta^{13} \mathrm{C}\end{array}$} & \multirow{2}{*}{$\begin{array}{l}\text { Depth } \\
\text { (mbsf) }\end{array}$} & \multicolumn{2}{|c|}{ G. sacculifer } & \multirow{2}{*}{$\begin{array}{l}\text { Pulleniatina } \\
\qquad \delta^{13} \mathrm{C}\end{array}$} & & G. sac & ulifer & \\
\hline & $\delta^{18} \mathrm{O}$ & $\delta^{13} \mathrm{C}$ & & & $\delta^{18} \mathrm{O}$ & $\delta^{13} \mathrm{C}$ & & $\begin{array}{l}\text { Depth } \\
\text { (mbst) }\end{array}$ & $\delta^{18} \mathrm{O}$ & $\delta^{13} \mathrm{C}$ & $\begin{array}{l}{ }^{13} \mathrm{C} \\
\end{array}$ \\
\hline $130-806 \mathrm{~B}-1 \mathrm{H}$ & & & & D-806B-2 & ont.) & & & $130-806 \mathrm{~B}-2 \mathrm{H}$ & ont.) & & \\
\hline 0.10 & -1.98 & 2.09 & 1.06 & 7.50 & -1.13 & 1.90 & 1.30 & 14.80 & -1.33 & 1.70 & 0.91 \\
\hline 0.20 & -1.86 & 1.93 & 1.03 & 7.60 & -1.07 & 2.05 & 1.34 & 14.90 & -1.49 & 1.98 & 1.14 \\
\hline 0.30 & -1.68 & 1.60 & 0.97 & 7.70 & -1.25 & 1.50 & 1.26 & 15.00 & -1.48 & 1.87 & 1.03 \\
\hline 0.40 & -1.48 & 1.91 & 1.23 & 7.80 & -1.27 & 2.07 & 1.28 & 15.09 & -1.31 & 1.40 & 1.07 \\
\hline 0.50 & -0.85 & 1.92 & 1.26 & 7.90 & -1.14 & 1.87 & 1.28 & 15.20 & -1.41 & 1.55 & 1.07 \\
\hline 0.60 & -1.01 & 1.91 & 1.36 & 7.99 & -1.46 & 1.61 & 1.30 & 15.30 & -1.49 & 1.27 & 0.77 \\
\hline 0.70 & -1.01 & 1.96 & 1.12 & 8.10 & -1.44 & 1.78 & 1.56 & 15.40 & -1.21 & 1.55 & 0.82 \\
\hline 0.80 & -1.07 & 1.95 & 1.13 & 8.20 & -1.73 & 1.97 & 1.28 & 15.49 & -1.05 & 1.44 & 0.78 \\
\hline 0.90 & -1.20 & 1.91 & 1.21 & 8.30 & -1.92 & 2.17 & 1.43 & 15.60 & -0.89 & 1.59 & \\
\hline 1.00 & -1.13 & 1.81 & 1.27 & 8.40 & -1.72 & 1.61 & 1.25 & 15.70 & -0.72 & 1.99 & 1.03 \\
\hline 1.10 & -1.19 & 1.70 & 1.27 & 8.50 & -1.71 & 1.61 & 1.24 & 15.78 & -1.01 & 1.52 & 1.03 \\
\hline 1.20 & -1.32 & 1.65 & 1.32 & 8.60 & -1.77 & 1.84 & 1.14 & 15.90 & -1.00 & 1.54 & 1.08 \\
\hline 1.30 & -1.33 & 1.53 & 1.06 & 8.70 & -1.55 & 1.72 & 0.87 & 16.00 & -1.07 & 1.62 & 0.85 \\
\hline 1.40 & -1.03 & 1.76 & 1.13 & 8.80 & -1.81 & 2.00 & & 16.10 & -0.97 & 1.74 & 0.87 \\
\hline 1.49 & $-1,11$ & 1.83 & 1.01 & 8.90 & -1.01 & 1.16 & 0.74 & 16.18 & -0.78 & 1.42 & 0.74 \\
\hline 1.60 & -1.44 & 2.18 & 1.35 & 9.00 & -0.44 & 1.65 & 1.23 & & & & \\
\hline 1.70 & -1.53 & 2.17 & 1.27 & 9.10 & -0.48 & 1.93 & 1.18 & $130-806 \mathrm{~B}-3 \mathrm{H}$ & & & \\
\hline 1.80 & -1.78 & 1.87 & 1.11 & 9.20 & -0.76 & 1.86 & 1.11 & & & & \\
\hline 1.90 & -1.40 & 2.08 & 1.44 & 9.30 & -0.76 & 1.96 & 1.16 & 16.10 & -0.07 & 1.44 & 0.92 \\
\hline 2.00 & -1.57 & 1.95 & 0.77 & 9.40 & -0.78 & 1.73 & 1.30 & 16.20 & -0.66 & 1.61 & 0.98 \\
\hline 2.10 & -1.63 & 1.83 & 1.18 & 9.49 & -0.84 & 1.72 & 1.40 & 16.40 & -0.80 & 1.48 & \\
\hline 2.20 & -1.76 & 1.40 & 0.93 & 9.60 & -0.75 & 1.67 & 1.37 & 16.50 & -0.70 & 1.71 & 1.20 \\
\hline 2.30 & -1.73 & 1.63 & 1.03 & 9.70 & -0.93 & 1.92 & 1.42 & 16.60 & -0.90 & 1.54 & 1.13 \\
\hline 2.40 & -1.72 & 1.78 & 1.15 & 9.80 & -0.93 & 2.00 & 1.51 & 16.70 & -0.98 & 1.51 & 0.93 \\
\hline 2.50 & -1.95 & 1.44 & & 9.90 & -1.00 & 1.91 & 1.41 & 16.80 & -1.24 & 1.51 & 0.96 \\
\hline 2.59 & -1.77 & 1.67 & 0.69 & 10.00 & -1.35 & 1.94 & 1.61 & 16.90 & -1.30 & 1.43 & 0.88 \\
\hline 2.70 & -1.65 & 1.34 & 0.71 & 10.10 & -1.43 & 2.17 & 1.62 & 17.00 & -1.12 & 1.71 & 0.92 \\
\hline 2.80 & -0.67 & 1.32 & 0.87 & 10.20 & -1.54 & 2.36 & 1.50 & 17.08 & -1.44 & 1.65 & 0.77 \\
\hline 2.90 & -0.84 & 1.66 & 1.04 & 10.30 & -1.72 & 2.24 & 1.56 & 17.19 & -1.33 & 1.76 & 0.80 \\
\hline 2.99 & -0.93 & 1.77 & & 10.40 & -1.50 & 1.98 & & 17.30 & -1.41 & 1.38 & 0.92 \\
\hline 3.10 & -0.66 & 1.59 & 0.77 & 10.50 & -1.38 & 1.90 & & 17.40 & -1.44 & 1.53 & 0.85 \\
\hline 3.20 & -0.86 & 1.44 & 0.82 & 10.60 & -1.29 & 2.03 & 1.34 & 17.49 & -1.34 & 1.77 & \\
\hline 3.30 & -0.98 & 1.42 & 0.80 & 10.70 & -1.31 & 1.99 & 1.21 & 17.60 & -1.66 & 1.25 & 0.72 \\
\hline 3.40 & -1.08 & 1.46 & 0.89 & 10.80 & -1.19 & 1.88 & 1.33 & 17.70 & -1.07 & 1.24 & 0.61 \\
\hline 3.50 & -1.08 & 1.30 & 0.67 & 10.90 & -1.44 & 1.76 & 1.35 & 17.90 & -0.69 & 1.34 & 0.77 \\
\hline 3.60 & -1.02 & 1.38 & 0.84 & 10.99 & -1.38 & 1.74 & 1.16 & 18.03 & -0.81 & 1.59 & 0.84 \\
\hline 3.70 & -0.99 & 1.35 & 0.50 & 11.10 & -1.15 & 1.83 & 1.07 & 18.12 & -0.70 & 1.22 & 0.82 \\
\hline 3.80 & -1.20 & 1.09 & 0.92 & 11.20 & -1.24 & 1.68 & & 18.20 & -0.59 & 1.39 & \\
\hline 3.90 & -1.34 & 1.66 & 1.01 & 11.30 & -0.95 & 1.61 & 1.08 & 18.30 & -1.15 & 1.62 & 1.02 \\
\hline 4.00 & -1.58 & 1.86 & 1.25 & 11.40 & -1.00 & 1.62 & 1.04 & 18.39 & -1.06 & 1.22 & 0.64 \\
\hline 4.09 & -1.52 & 1.57 & 0.86 & 11.50 & -1.00 & 1.85 & 1.00 & 18.50 & -0.93 & 1.20 & 0.65 \\
\hline 4.15 & -1.66 & 1.51 & 1.07 & 11.60 & -1.08 & 1.67 & 1.19 & 18.60 & -0.95 & 1.13 & 0.53 \\
\hline 4.60 & -1.25 & 1.50 & 0.80 & 11.70 & -1.02 & 1.79 & 1.04 & 18.69 & -1.01 & 1.32 & 0.67 \\
\hline 4.70 & -1.14 & 1.65 & 0.90 & 11.80 & -1.36 & 1.79 & 1.13 & 18.80 & -0.91 & 1.43 & 0.59 \\
\hline 4.80 & -1.31 & 1.75 & 0.97 & 11.90 & -1.36 & 1.58 & 1.01 & 19.10 & -1.34 & 1.57 & 0.71 \\
\hline 4.90 & -1.30 & 1.53 & 1.08 & 12.00 & -1.13 & 1.88 & 1.16 & 19.20 & -1.42 & 1.86 & 0.88 \\
\hline 5.00 & -1.68 & 1.72 & 0.94 & 12.09 & -1.54 & 2.00 & 1.18 & 19.40 & -1.48 & 1.74 & 0.89 \\
\hline 5.10 & -1.55 & 1.64 & 0.61 & 12.20 & -1.56 & 2.12 & 1.03 & 19.50 & -1.36 & 1.26 & 0.87 \\
\hline 5.20 & -1.59 & 1.31 & 0.77 & 12.30 & -1.41 & 1.69 & 0.85 & 19.60 & -1.21 & 1.46 & 0.86 \\
\hline 5.30 & -0.98 & 1.60 & 0.88 & 12,40 & -1.47 & 2.06 & 0.96 & 19.70 & -1.39 & 1.43 & 0.75 \\
\hline 5.40 & -1.19 & 1.79 & 0.94 & 12.60 & -0.91 & 1.83 & 0.96 & 19.80 & -1.30 & 1.27 & 0.79 \\
\hline 5.50 & -1.01 & 1.26 & 0.85 & 12.70 & -1.43 & 1.76 & 1.15 & 19.90 & -1.19 & 1.62 & 0.80 \\
\hline 5.59 & -0.87 & 1.39 & 0.70 & 12.80 & -1.36 & 1.75 & 1.08 & 20.00 & -1.03 & 1.81 & \\
\hline 5.69 & -0.94 & 1.55 & 1.08 & 12.90 & -1.20 & 1.76 & 1.20 & 20.08 & -1.26 & 1.83 & 0.97 \\
\hline 5.80 & -0.86 & 1.83 & 0.99 & 13.00 & -1.30 & 2.22 & & 20.19 & -1.17 & 1.47 & 1.09 \\
\hline 5.90 & -1.17 & 1.78 & 1.06 & 13.10 & -1.47 & 1.61 & & 20.30 & -1.26 & 1.70 & 1.03 \\
\hline 5.99 & -1.34 & 1.77 & 1.16 & 13.20 & -1.32 & 1.71 & 1.13 & 20.40 & -1.62 & 1.83 & 0.89 \\
\hline 6.10 & -1.26 & 1.76 & 1.11 & 13.30 & -1.48 & 1.59 & 0.96 & 20.49 & -1.32 & 1.66 & 0.88 \\
\hline 6.20 & -1.35 & 1.84 & 1.25 & 13.40 & -1.54 & 1.31 & 0.90 & 20.60 & -1.35 & 2.07 & 1.18 \\
\hline 6.30 & -1.02 & 1.71 & & 13.50 & -0.99 & 1.06 & 0.65 & 20.70 & -1.17 & 2.04 & 1.09 \\
\hline & & & & 13.59 & -0.52 & 1.43 & 0.97 & 20.90 & -1.15 & 1.93 & 0.75 \\
\hline $130-806 \mathrm{~B}-2 \mathrm{H}$ & & & & 13.70 & -0.63 & 1.57 & 0.54 & 21.00 & -1.08 & 1.50 & 0.71 \\
\hline & & & & 13.80 & -0.74 & 1.64 & 0.85 & 21.10 & -1.13 & 1.79 & 0.96 \\
\hline 6.60 & -1.52 & 1.48 & 1.21 & 13.90 & -0.63 & 1.62 & 0.90 & 21.22 & -1.10 & 1.85 & 1.16 \\
\hline 6.70 & -1.23 & 1.57 & 1.00 & 13.99 & -0.68 & 1.55 & 0.73 & 21.30 & -1.31 & 1.72 & 0.98 \\
\hline 6.80 & -1.38 & 1.57 & 1.01 & 14.10 & -0.87 & 1.57 & 0.73 & 21.40 & -1.31 & 1.33 & 1.04 \\
\hline 6.90 & -1.26 & 1.33 & 1.06 & 14.20 & -1.03 & 1.09 & 0.92 & 21.50 & -1.28 & 1.62 & 0.90 \\
\hline 7.00 & -1.31 & 1.26 & 1.00 & 14.30 & -0.83 & 1.54 & 0.80 & 21.60 & -1.27 & 1.70 & 0.82 \\
\hline 7.10 & -0.92 & 1.61 & 0.94 & 14.37 & -0.88 & 1.37 & & 22.10 & -1.13 & 1.33 & \\
\hline 7.20 & -0.70 & 1.71 & 1.13 & 14.50 & -0.83 & 1.49 & 0.88 & 22.20 & -1.02 & 1.39 & 0.87 \\
\hline 7.30 & -0.75 & 1.92 & 1.28 & 14.60 & -1.00 & 1.80 & 1.01 & 22.40 & -1.52 & 1.65 & 0.98 \\
\hline 7.40 & -1.08 & 2.03 & 1.29 & 14.70 & -0.80 & 1.73 & 1.00 & 22.50 & -1.44 & 1.85 & 0.94 \\
\hline
\end{tabular}


APPENDIX (continued).

\begin{tabular}{|c|c|c|c|c|c|c|c|c|c|c|c|}
\hline \multirow{2}{*}{$\begin{array}{l}\text { Depth } \\
\text { (mbsf) }\end{array}$} & \multicolumn{2}{|c|}{ G. sacculifer } & \multirow{2}{*}{$\begin{array}{l}\text { Pulleniatina } \\
\qquad \delta^{13} \mathrm{C}\end{array}$} & \multirow{2}{*}{$\begin{array}{l}\text { Depth } \\
\text { (mbsf) }\end{array}$} & \multicolumn{2}{|c|}{ G. sacculifer } & \multirow{2}{*}{$\begin{array}{l}\text { Pulleniatina } \\
\qquad \delta^{13} \mathrm{C}\end{array}$} & & G. sac & elifer & \\
\hline & $\delta^{18} \mathrm{O}$ & $\delta^{13} \mathrm{C}$ & & & $\delta^{18} \mathrm{O}$ & $\delta^{13} \mathrm{C}$ & & (mbsf) & $\delta^{18} \mathrm{O}$ & $\delta^{13} \mathrm{C}$ & $\delta^{13} \mathrm{C}$ \\
\hline $130-806 \mathrm{~B}-3 \mathrm{H}$ & nt.) & & & $130-806 \mathrm{~B}-4 \mathrm{H}$ & nt.) & & & $130-806 \mathrm{~B}-5$ & nt.) & & \\
\hline 22.60 & -1.76 & 2.10 & 1.03 & 30.10 & -1.38 & 1.61 & 1.06 & 37.20 & -1.14 & 1.86 & 0.79 \\
\hline 22.70 & -1.30 & 1.67 & 0.62 & 30.20 & -1.40 & 1.89 & 0.94 & 37.30 & -1.43 & 2.02 & 0.86 \\
\hline 22.80 & -1.87 & 1.13 & 0.89 & 30.30 & -1.50 & 2.08 & 0.85 & 37.40 & -1.44 & 2.15 & 0.99 \\
\hline 22.90 & -1.50 & 1.44 & 0.83 & 30.42 & -1.70 & 1.91 & 0.87 & 37.50 & -1.38 & 1.84 & 0.84 \\
\hline 23.00 & -1.32 & 1.58 & 0.92 & 30.50 & -1.72 & 2.04 & 0.98 & 37.58 & -1.20 & 2.09 & 0.72 \\
\hline 23.12 & -1.18 & 1.53 & 0.88 & 30.60 & -1.65 & 1.71 & 0.72 & 37.69 & -1.16 & 1.97 & 0.68 \\
\hline 23.19 & -1.00 & 1.59 & 0.93 & 30.70 & -1.66 & 1.60 & 0.63 & 37.80 & -1.11 & 1.81 & 0.81 \\
\hline 23.30 & -1.32 & 1.73 & 0.96 & 30.80 & -1.18 & 1.34 & 0.70 & 37.90 & -1.15 & 1.78 & 0.92 \\
\hline 23.40 & -1.26 & 1.67 & 1.19 & 30.90 & -1.06 & 1.57 & 1.04 & 37.99 & -1.06 & 1.98 & 0.95 \\
\hline 23.49 & -1.38 & 1.92 & 0.81 & 31.00 & -0.73 & 1.85 & 1.23 & 38.10 & -1.35 & 2.00 & 1.01 \\
\hline 23.60 & -1.44 & 1.93 & 0.38 & 31.12 & -1.10 & 1.87 & 0.93 & 38.20 & -1.16 & 1.93 & 1.11 \\
\hline 23.70 & -0.85 & 1.34 & 0.56 & 31.20 & -1.35 & 2.22 & 1.13 & 38.30 & -1.11 & 1.79 & 1.05 \\
\hline 23.90 & -1.01 & 1.69 & 0.77 & 31.31 & -1.43 & 2.37 & 1.11 & 38.50 & -1.08 & 1.80 & 0.97 \\
\hline 24.00 & -1.12 & 1.49 & 0.87 & 31.40 & -1.52 & 2.29 & 1.02 & 38.60 & -1.03 & 1.86 & 0.94 \\
\hline 24.10 & -1.09 & 1.58 & 1.18 & 31.60 & -1.55 & 2.26 & 1.20 & 38.70 & -1.08 & 1.95 & 1.07 \\
\hline 24.20 & -1.26 & 2.09 & 1.15 & 31.70 & -1.56 & 1.91 & 1.23 & 38.80 & -1.11 & 1.88 & 1.04 \\
\hline 24.30 & -1.42 & 1.88 & 1.15 & 31.80 & -1.41 & 1.88 & 0.85 & 38.90 & -1.07 & 1.55 & 1.02 \\
\hline 24.40 & -1.40 & 1.86 & 1.07 & 31.92 & -1.11 & 1.58 & 0.99 & 39.00 & -1.19 & 1.68 & 1.03 \\
\hline 24.50 & -1.10 & 1.63 & 1.05 & 32.00 & -0.98 & 1.48 & 1.10 & 39.08 & -1.19 & 1.69 & 0.84 \\
\hline 24.60 & -1.08 & 1.73 & 0.95 & 32.10 & -1.24 & 2.20 & 1.22 & 39.19 & -1.26 & 1.63 & 0.86 \\
\hline 24.69 & -1.17 & 1.48 & 0.90 & 32.20 & -1.29 & 1.95 & 1.35 & 39.30 & -1.22 & 1.74 & 0.77 \\
\hline 24.80 & -1.57 & 1.76 & 1.04 & 32.30 & -1.52 & 2.45 & 0.66 & 39.40 & -1.09 & 1.59 & 0.70 \\
\hline 24.90 & -1.25 & 1.63 & 1.04 & 32.40 & -1.45 & 1.84 & 1.01 & 39.49 & -0.98 & 1.56 & 0.59 \\
\hline 24.99 & -1.19 & 1.56 & 0.85 & 32.50 & -1.50 & 1.98 & 0.91 & 39.60 & -1.00 & 1.50 & 0.78 \\
\hline 25.10 & -1.16 & 1.74 & 0.75 & 32.62 & -1.06 & 1.71 & 0.48 & 39.70 & -0.88 & 1.66 & 0.90 \\
\hline 25.20 & -1.08 & 1.77 & 0.97 & 32.81 & -0.96 & 2.06 & 1.09 & 39.80 & -1.01 & 1.73 & 0.81 \\
\hline 25.40 & -1.11 & 1.74 & 0.99 & 32.90 & -1.01 & 2.04 & 0.94 & 40.00 & -0.90 & 1.42 & 0.83 \\
\hline 25.50 & -1.10 & 1.50 & 0.76 & 32.99 & -1.41 & 2.14 & 0.83 & 40.10 & -1.07 & 1.85 & 1.06 \\
\hline 25.60 & -1.19 & 1.74 & 0.96 & 33.10 & -1.24 & 2.05 & 0.99 & 40.20 & -0.96 & 2.05 & 1.17 \\
\hline 25.70 & -1.31 & 1.82 & 1.24 & 33.20 & -1.71 & 2.61 & 1.17 & 40.30 & -1.18 & 1.95 & 1.06 \\
\hline & & & & 33.30 & -1.42 & 2.34 & 0.97 & 40.40 & -1.22 & 1.80 & 1.20 \\
\hline $130-806 \mathrm{~B}-4 \mathrm{H}$ & & & & 33.42 & -1.23 & 2.02 & 0.92 & 40.50 & -1.40 & 1.83 & 1.10 \\
\hline & & & & 33.50 & -1.16 & 2.37 & 0.98 & 40.57 & -1.28 & 1.76 & 0.92 \\
\hline 25.60 & -1.21 & 1.48 & 0.95 & 33.60 & -1.16 & 2.12 & & 40.70 & -1.19 & 1.68 & 0.71 \\
\hline 25.70 & -1.23 & 1.68 & 1.00 & 33.70 & -1.30 & 1.98 & 0.95 & 40.80 & -0.92 & 1.43 & 0.73 \\
\hline 26.00 & -1.62 & 2.09 & 1.09 & 33.80 & -1.35 & 2.05 & 1.15 & 40.90 & -0.93 & 1.36 & 0.75 \\
\hline 26.10 & -1.69 & 1.82 & 1.03 & 33.90 & -1.26 & 1.99 & 0.93 & 41.10 & -1.06 & 1.76 & 1.09 \\
\hline 26.20 & -0.97 & 1.56 & 0.60 & 34.00 & -1.56 & 2.01 & 1.03 & 41.20 & -0.96 & 2.05 & 1.16 \\
\hline 26.30 & -0.91 & 1.74 & 0.80 & 34.12 & -1.33 & 2.09 & 1.01 & 41.30 & -1.18 & 1.88 & 1.22 \\
\hline 26.42 & -1.21 & 1.97 & 0.72 & 34.31 & -1.30 & 1.99 & 0.88 & 41.41 & -1.35 & 2.19 & 1.06 \\
\hline 26.70 & -1.67 & 2.32 & 1.20 & 34.40 & -1.25 & 1.53 & 0.71 & 41.50 & -1.27 & 2.13 & 1.09 \\
\hline 26.81 & -1.29 & 2.08 & 0.85 & 34.49 & -1.11 & 1.98 & 1.08 & 41.60 & -1.35 & 1.83 & 1.14 \\
\hline 26.90 & -1.17 & 1.28 & 0.81 & 34.60 & -1.26 & 1.80 & 1.05 & 41.70 & -0.99 & 1.81 & 0.98 \\
\hline 26.99 & -1.19 & 1.63 & 0.70 & 34.70 & -1.53 & 2.16 & 0.99 & 41.80 & -1.09 & 1.88 & 1.09 \\
\hline 27.10 & -1.05 & 1.62 & & 34.80 & -1.47 & 2.17 & 1.17 & 41.90 & -1.11 & 1.94 & 1.12 \\
\hline 27.20 & -0.97 & 1.77 & & 34.92 & -1.42 & 2.15 & & 42.00 & -0.96 & 1.77 & 1.02 \\
\hline 27.25 & -1.26 & 1.76 & & 35.00 & -1.44 & 1.95 & 0.87 & 42.08 & -1.19 & 1.93 & 1.11 \\
\hline 27.40 & -1.15 & 2.04 & 1.16 & 35.10 & -1.49 & 1.61 & 0.70 & 42.20 & -1.21 & 2.26 & 1.26 \\
\hline 27.50 & -1.40 & 2.00 & 0.96 & 35.21 & -1.28 & 1.64 & 0.73 & 42.30 & -1.13 & 1.98 & 1.21 \\
\hline 27.60 & -1.25 & 1.65 & 1.26 & & & & & 42.40 & -1.14 & 2.08 & 1.26 \\
\hline 27.70 & -1.32 & 2.15 & 0.90 & $130-806 \mathrm{~B}-5 \mathrm{H}$ & & & & 42.49 & -1.31 & 2.27 & 1.13 \\
\hline 27.80 & -1.42 & 1.73 & 0.61 & & & & & 42.60 & -1.23 & 2.17 & 1.26 \\
\hline 27.91 & -1.18 & 1.54 & 0.64 & 35.10 & -1.26 & 1.81 & 1.00 & 42.70 & -1.12 & 1.75 & 0.90 \\
\hline 28.00 & -0.99 & 1.63 & 0.70 & 35.20 & -1.05 & 1.50 & 0.87 & 42.80 & -1.37 & 1.90 & 1.04 \\
\hline 28.11 & -1.25 & 1.68 & 0.74 & 35.30 & -1.16 & 1.53 & 1.00 & 43.00 & -1.11 & 1.72 & 1.17 \\
\hline 28.31 & -1.33 & 1.93 & 1.20 & 35.41 & -1.32 & 1.31 & 0.75 & 43.10 & -1.03 & 1.94 & 1.13 \\
\hline 28.40 & -1.55 & 1.89 & 1.10 & 35.50 & -1.62 & 1.80 & 0.67 & 43.20 & -1.11 & 1.87 & 0.92 \\
\hline 28.49 & -1.67 & 2.02 & 1.03 & 35.60 & -1.51 & 1.77 & 0.95 & 43.30 & -1.03 & 1.84 & 0.97 \\
\hline 28.60 & -1.47 & 2.05 & 0.80 & 35.70 & -1.23 & 1.75 & 0.94 & 43.40 & -1.16 & 1.61 & 0.93 \\
\hline 28.70 & -1.37 & 1.84 & 0.61 & 35.80 & -1.28 & 1.79 & 0.79 & 43.50 & -1.20 & 1.81 & 0.88 \\
\hline 28.79 & -1.27 & 1.76 & 0.65 & 35.90 & -1.04 & 1.34 & 0.68 & 43.58 & -1.16 & 1.73 & 0.89 \\
\hline 28.91 & -1.39 & 1.65 & & 36.00 & -1.03 & 1.64 & 0.95 & 43.70 & -1.09 & 1.55 & 0.75 \\
\hline 29.00 & -1.37 & 1.74 & 0.63 & 36.07 & -1.11 & 1.59 & 0.89 & 43.80 & -1.27 & 1.77 & 0.94 \\
\hline 29.10 & -1.01 & 1.88 & 0.96 & 36.18 & -1.22 & 1.91 & 0.81 & 43.90 & -0.85 & 1.61 & 0.57 \\
\hline 29.20 & -1.17 & 2.15 & 0.90 & 36.30 & -1.48 & 1.81 & 0.62 & 43.99 & -1.03 & 1.41 & \\
\hline 29.30 & -1.63 & 2.19 & 0.92 & 36.40 & -1.37 & 1.72 & 0.83 & 44.10 & -0.91 & 1.80 & 0.79 \\
\hline 29.41 & -1.52 & 2.18 & 1.03 & 36.49 & -1.30 & 1.52 & 0.68 & 44.20 & -1.22 & 1.73 & 0.53 \\
\hline 29.50 & -1.52 & 2.14 & 1.05 & 36.60 & -1.10 & 1.76 & 0.64 & 44.30 & -1.04 & 1.58 & 0.81 \\
\hline 29.61 & -1.47 & 1.85 & 0.50 & 36.70 & -1.06 & 1.33 & 0.66 & 44.50 & -1.19 & 1.98 & 0.94 \\
\hline 29.81 & -1.53 & 1.48 & 0.74 & 36.80 & -0.94 & 1.57 & 0.60 & 44.60 & -0.91 & 1.50 & 0.83 \\
\hline 29.90 & -1.14 & 1.39 & 0.75 & 37.00 & -1.05 & 1.71 & 1.11 & 44.70 & -1.23 & 1.95 & 1.05 \\
\hline 29.99 & -1.28 & 1.65 & 0.95 & 37.10 & -1.18 & 1.93 & 1.08 & & & & \\
\hline
\end{tabular}

Note: Oxygen isotope data from Berger et al. (this volume, table 1). 